\title{
Does Tax-Collection Invariance Hold? Evasion and the Pass-Through of State Diesel Taxes
}

\author{
By WOJCIECH KOPCZuK, Justin MARION, \\ ERICH Muehlegger, AND Joel SLemrod*
}

\begin{abstract}
In simple models, the incidence of a tax is independent of the identity of the remitting party. We illustrate that this prediction fails to hold if opportunities for evasion differ across economic agents. Second, we estimate how the incidence of state diesel taxes varies with the point of collection, where the remitting party varies across states and over time. Moving tax collection upstream from retailers substantially raises the pass-through of diesel taxes to consumers. Furthermore, tax revenues increase when collecting taxes from wholesalers rather than from retailers, suggesting that evasion is the likely explanation for the incidence result. (JEL H22, H25, H26, H71, L71)
\end{abstract}

$\checkmark$ The independence between statutory and economic incidence of a tax is a well-known and widely accepted result in the theory of taxation. The textbook presentation of the theory of tax incidence holds that the party responsible for remitting the tax to the government has no impact on who actually bears the burden, at least in the long run. Despite its prominent treatment, this result holds only under special circumstances. The primary contribution of this paper is to illustrate a new way in which the independence of economic incidence from the remittance regime may break down. If parties differ in their ability to evade taxes, the identity of the tax remitter may impact the pattern of post-tax prices and therefore the location of their burden. Due to different evasion technologies available to the different sides of a market, a tax levied on the demand side may shift the demand curve to a different degree than a similar tax levied on supply side would shift the supply curve.

This issue is relevant to the current debate on whether a carbon tax should be levied on upstream suppliers or downstream users. Opportunities to avoid taxes vary

\footnotetext{
* Kopczuk: Department of Economics, Columbia University, 1022 International Affairs Building, MC 3308, 420 West 118th Street, New York, NY 10027 (e-mail: wk2110@ columbia.edu); Marion: Department of Economics, University of California-Santa Cruz (UC Santa Cruz), Engineering II, Santa Cruz, CA 95064 (e-mail: marion@ ucsc.edu); Muehlegger: Department of Economics, University of California-Davis (UC Davis), One Shields Avenue, Davis, CA 95616 (e-mail: emuehlegger@ucdavis.edu); Slemrod: Stephen M. Ross School of Business, University of Michigan, 701 Tappan Street, R5396, Ann Arbor, MI 48109 (e-mail: jslemrod@umich.edu). Harold Stolper and Ajin Lee provided excellent research assistance. We wish to thank the three anonymous referees and seminar participants at Cornell University, University of Maryland, Dartmouth College, Drexel University, Harvard University, University of Pennsylvania Wharton School, UC Davis, UC Santa Cruz, McMaster Univerity, the National Tax Association Annual Conference, the Institute for Fiscal Studies, the American Economic Association Meetings, and the first Northeast Workshop on Energy Policy and Environmental Economics at Cornell University for helpful comments.

Go to http://dx.doi.org/10.1257/pol.20140271 to visit the article page for additional materials and author disclosure statement $(\mathrm{s})$ or to comment in the online discussion forum.
} 
at different points in the supply chain. Although a number of papers (e.g., Metcalf 2009; Niemeier et al. 2008; Fischer, Kerr, and Toman 1998) highlight the administrative, distributional, and political advantages of levying a carbon tax at different points in the supply chain, the literature largely assumes away an impact on the incidence of taxes. For example, Metcalf (2009) notes "One might argue that it would be better to levy the tax downstream because the carbon price would be more visible to end users and thus more likely to figure into energy consumption and planning decisions. Such an argument ignores a basic principle of tax incidence analysis: the ultimate burden and behavioral response to a tax does not depend on where in the production process the tax is levied." Similarly, Fischer, Kerr, and Toman (1998) comments " ... a downstream approach will have the same ultimate effects on fossil fuel and other prices as an upstream program. This corollary of the basic proposition that the ultimate incidence of a tax is independent of where it is applied is frequently misunderstood by proponents of downstream-based GHG emissions trading."

In this paper, we empirically examine how the identity of the tax remitter affects incidence in the diesel fuel market and present empirical evidence that the identity of the remitting party affects both collections and the incidence of taxes. Our context is state diesel fuel taxes. States differ in the stage of the supply chain responsible for remitting the tax (none require final consumer remittance), and over time states have in general moved the point of tax collection to higher in the supply chain. In the early 1980s, states were almost evenly split between collecting taxes from retail stations and collecting from intermediate wholesale distributors. Over the subsequent 20 years, many states have moved away from collecting from retail stations and toward collecting from prime suppliers. States changed tax collection regimes at different points in time, a fact that we will exploit in this paper.

In addition to the considerable variation in the point of collection, the nature of tax evasion in the diesel market makes it a desirable setting for studying the effect of remittance on incidence. Several factors contribute to creating opportunities for evading diesel taxes. Due to fixed per firm costs, it is relatively costly to monitor the remittance of the tax when there are many remitters each responsible for a small fraction of total revenue, as when taxes are collected from retail stations. Also, variation in tax rates across jurisdictions and across the uses of diesel create opportunities for misstating the ultimate state of sale or the intended use of a gallon of diesel. ${ }^{1,2}$ Importantly, the opportunities for evasion differ considerably across the stages of the supply chain. For instance, hiding taxed sales is more difficult for prime suppliers because they are relatively less costly to monitor. On the other hand, a gallon of diesel sold at the retail level is usually intended for on-highway use, so retailers will find it more difficult to evade by misstating the intended use or state of sale. Which form of evasion is more important for tax collection is an empirical matter.

We find that the rate of pass-through of diesel taxes to retail prices is dependent on the location of remittance responsibility. Retail diesel prices are higher, and diesel taxes are passed through to retail prices to a greater extent, in states where the

\footnotetext{
${ }^{1}$ When we refer to a "tax rate," we mean the per unit quantity tax rather than a percent rate.

${ }^{2}$ As we discuss below, the rate of tax on diesel fuel depends on whether the fuel is used for residential heating or for commercial purposes.
} 
point of collection is at the distributor or prime supplier level rather than at the retail level. This suggests that this collection regime reduces evasion. Lending credence to this result, we are able to trace the impact of collecting at the prime supplier level through the supply chain. An increase in the tax raises the tax-exclusive wholesale price in supplier-remitting states, although not in retailer-remitting states. Moreover, conditional on the wholesale price, supplier remittance has no effect on pass-through. In other words, the effect of an increase in taxes on retail prices in supplier-remitting states can be entirely explained via their effect on wholesale prices.

To examine tax evasion as an explanation for this result, we estimate the response of tax collections to the point of tax collection. We find evidence suggesting that, ceteris paribus, states see less tax revenue when taxes are collected at the retail level. This is consistent with the incidence results, which suggest that retailers have more ability to evade taxes than firms at higher levels of the supply chain.

The tax collection regime is unlikely to be randomly assigned, and may be chosen in a way that maximizes revenues or minimizes the cost of tax collection. While this may suggest that our estimated effects of the tax collection regime are local, heterogenous treatment effects are less of a concern in this paper since we are merely testing a null hypothesis of tax collection regime having no effect on the pass-through of prices. More importantly, however, there is the concern that unobserved variables may influence both evasion and the tax regime. To alleviate such concerns, we exploit the timing of changes in tax collection regime, showing that both incidence and collections change discontinuously at the date of the change in remitting party.

The tax literature has recognized for some time the importance of tax administration and collection, such as Musgrave (1969). Sørensen (1994), Kau and Rubin (1981), and Balke and Gardner (1991) suggest links between the size of government or the structure of tax systems and tax administration. However, theoretical work has largely ignored the implications of evasion and tax collection on incidence, with a possible exception being Tanzi (1992). Slemrod (2008) suggests that statutory and economic incidence are not necessarily independent in the presence of evasion, and discusses the conditions under which the textbook invariance principle fails.

Despite its prominent place in the theory of taxation, there is scant empirical work testing the independence of economic and statutory incidence in real-world markets. ${ }^{3}$ Saez, Matsaganis, and Tsakloglou (2012) examine the payroll tax in Greece, where a rule change extended the earnings cap for individuals starting work in 1993 or later. They find that the increase in the employer portion of the tax was passed through to wages, while the employee portion was not, perhaps since posted salaries exclude the employer portion of the payroll tax. In contrast, Muysken, Veen, and Regt (1999) estimate the nominal wage rate as a function of employer taxes and employee taxes in the Netherlands with national data from 1960-1995. The paper estimates that 44 percent of employee taxes are borne by firms while firms bear the entirety of employer taxes. Hence, shifting the statutory burden from employers to

\footnotetext{
${ }^{3}$ A related literature (e.g., , Hayashi, Nakamura, and Gamage 2013 and Fochmann and Weimann 2013) experimentally tests the equivalence of payroll and income taxes and find that the framing of a tax affects the provision of labor and effort in the laboratory. This literature focusing on behavioral explanations for the nonequivalence taxes levied on workers and firms is less relevant to our case in which the taxes remitted by different points in the supply chain are identical from the consumer's perspective.
} 
employees may reduce wage costs. Lehmann, Marical, and Rioux (2013) examine the response of labor income to changes in marginal and average income and payroll tax rates. They find slight responses to changes in income tax rates, but no evidence of a response to changes in payroll tax rates. In all three cases, the authors suggest that institutional factors, such as wage rigidity, may play an important role in the incidence of a tax.

In contrast to the existing literature on national taxation of labor markets, we examine state diesel taxes. State diesel taxes are particularly attractive for examining the relationship between the point of collection and tax pass-through. In particular, we observe hundreds of tax changes, within-state changes in the point of collection, and variation in the extent of tax evasion at different points in the supply chain. Furthermore, diesel taxes are a context in which many of the existing explanations such as wage rigidity and behavioral biases are unlikely to apply.

Finally, there are a number of papers related to this work that study tax enforcement as well as the pass-through of fuel taxes and excise taxes on other goods. De Paula and Scheinkman (2010) study the nature of tax enforcement and how it affects parties throughout the supply chain in the context of the value-added tax (VAT). They show that the self-enforcing nature of the VAT leads to spillovers in informality between firms at neighboring levels of the supply chain. In related work, Pomeranz (2013) finds in a randomized field experiment that random audit announcements are transmitted to the compliance behavior of firms up the supply chain.

Prior empirical work has examined evasion and enforcement of diesel taxes. Marion and Muehlegger (2008) study the dyeing of untaxed diesel, a key enforcement innovation in the United States. Agostini and Martínez (2014) study the tax reporting effects of audit threats in Chile.

A handful of recent studies have estimated the pass-through rate of fuel taxes to retail prices. Doyle and Samphantharak (2008) estimate the effect of gas tax holidays in Illinois and Indiana on retail prices. Marion and Muehlegger (2011) estimate the dependence of the pass-through rate of fuel taxes on a variety of factors related to supply conditions in the fuel market. Other relevant work in the pass-through rate of fuel taxation includes Alm, Sennoga, and Skidmore (2009); Chouinard and Perloff (2004); and Chouinard and Perloff (2007). ${ }^{4}$ The literature related to the pass-through rate of retail sales taxes broadly is more sparse, as suggested by Poterba (1996). Besley and Rosen (1999), who estimate the pass-through rate of city sales taxes to prices for 12 commodities, is an exception. A number of papers including Sunng, $\mathrm{Hu}$, and Keeler (1994); Barnett, Keeler, and Hu (1995); Delipalla and O'Donnell (2001); Harding, Leibtag, and Lovenheim (2012); and Chiou and Muehlegger (2014) estimate cigarette tax incidence. A smaller literature has examined the incidence of labor market taxes, which are often assumed to be fully borne by workers (e.g., Fullerton and Metcalf 2002). Rothstein (2010) finds that the EITC expansion in the 1990s reduced wages among low-skilled workers, so that low-skilled single

\footnotetext{
${ }^{4}$ Early empirical work on incidence includes Due (1954), Brownlee and Perry (1967), Woodard and Siegelman (1967), and Sidhu (1971). Chernick and Reschovsky (1997) consider the distributional impact of the gasoline tax by examining gasoline expenditures across different deciles of the income and expenditure distribution.
} 
mothers benefited by only 70 cents per dollar of tax credits received. Wages declined for non-eligible low-skilled workers as well, which resulted in employers benefiting by 72 cents for every dollar of benefits.

The rest of the paper proceeds as follows. Section I analyzes a model of the evasion decision and describes under what circumstances statutory incidence alters economic incidence. Section II provides relevant institutional details. Section III describes the data and methodology. Section IV describes the empirical results regarding pass-through and the effect of remittance on tax compliance. Section V concludes.

\section{Pass-Through in the Presence of Tax Evasion}

Standard models of tax incidence treat compliance and monitoring as costless activities, which is a simplification that in many circumstances does not hold and could have important implications for the distribution of the burden of taxation. To see this, consider the demand and supply sides of a market, where these can either be thought of as consumers and firms, or alternatively two different levels of a supply chain. For now, we will refer to consumers and retail firms, and then generalize explicitly to multiple layers of supply chain.

In equilibrium, price equates demand and supply: $D(p)=S(p)$. Introducing a per unit tax that must be remitted by suppliers alters this equilibrium to $D\left(p_{r}\right)$ $=S\left(p_{r}-t_{r}\right)$, where $p_{r}$ denotes the retail price faced by consumers and $t_{r}$ is the retail stage per unit tax. Alternatively, a similar tax that is instead remitted by the demand side of the market results in an equilibrium price $p_{r}^{p}$ (price received by producers selling to the retail consumers) such that $D\left(p_{r}^{p}+t_{r}\right)=S\left(p_{r}^{p}\right)$. The quantity sold and the pattern of net-of-tax prices must be the same in these two equilibria, where $p_{r}^{p}+t_{r}=p_{r} \cdot{ }^{5}$

This irrelevance result is driven by demand and supply depending only on the total tax-inclusive prices. Allowing for differences in either the evasion technology or the cost of monitoring across the demand and supply sides of the market potentially alters this conclusion. Consider the possibility that demand or supply depends not just on the relevant prices but also on the tax rate remitted by each side: the overall tax rate remains $t_{r}$, but $t_{s}$ of it is to be remitted by the suppliers and $t_{r}-t_{s}$ by the consumers, so that the demand is given by $D\left(p_{r}^{p}+t_{r}, t_{r}-t_{s}\right)=S\left(p_{r}^{p}, t_{s}\right)$. Due to differences between the two sides of the market in terms of the potential for tax evasion or compliance costs, or due to behavioral or institutional reasons, demand and/ or supply can depend on the remittance responsibility independently of the price.

Supply in the Presence of Tax Evasion.-To make our argument more concrete, simply consider a profit-maximizing firm that - conditional on entering the industry - sets output $q$ and the level of tax evasion $e$ to maximize $\pi(q, e)=p_{r}^{p} q+$ $t_{s} e-C(q, e)$. Revenue depends on the price that it charges, $p_{r}^{p}$. Some of tax revenue that should be remitted may be concealed, $t_{s} e$. The function $C(q, e)$ reflects the cost

\footnotetext{
${ }^{5}$ We will assume throughout perfect competition, as this argument survives considering market power. See the online Appendix for details.
} 
of producing output and any compliance costs, concealment expenditures, the cost of bearing risk, and penalties. We assume that $C(\cdot)$ is jointly convex in its arguments. Note that, although the general level of the tax $t_{r}$ is relevant only through its effect on the output price, the firm's own remittance responsibility $t_{s}$ has an independent effect. This formulation gives rise to firm's supply $q\left(p_{r}^{p}, t_{s}\right)$ and it's straightforward to show that $\frac{\partial q}{\partial p_{r}^{p}}>0, \frac{\partial e}{\partial t_{s}}>0$ and that $\frac{\partial q}{\partial t}=\frac{\partial e}{\partial p_{r}^{p}}=-\frac{C_{e q}}{C_{q q} C_{e e}-C_{e q}^{2}}$, so that the sign of these cross-derivatives is the opposite of the sign of $-C_{e q}$ (because the denominator is positive by the convexity of $C(\cdot))$. In particular, output (weakly) increases in the remittance component of the tax rate $t_{s}$ as long as $C_{e q} \leq 0$; this is a natural assumption to make because it simply corresponds to a larger level of output facilitating a given amount of tax evasion. The second way in which remittance responsibility would affect output is via entry of firms. By the envelope theorem, $\frac{d \pi}{d t_{s}}=e \geq 0$, so that higher remittance unambiguously leads to more entry, holding price constant. Hence, with both output channels working in the same direction under natural assumptions, the assumption of $\frac{\partial S}{\partial t_{S}}>0$ is compelling to make. Because there are no consumer-side taxes in the empirical analysis, we refrain from modeling this aspect, but note here that it is also natural to expect that $\frac{\partial D}{\partial t} \geq 0$.

Comparative Statics of Shifting Remittance Responsibility.-It is easy to show, by differentiating the equilibrium condition $D\left(p_{r}^{p}+t_{r}, t_{r}-t_{s}\right)=S\left(p_{r}^{p}, t_{s}\right)$ with respect to $t_{s}$, that the effect of a change in the remittance responsibility of each side, holding constant the statutory tax rate, will in general alter the equilibrium price:

$$
\frac{d p_{r}}{d t_{s}}=\frac{d p_{r}^{p}}{d t_{s}}=\frac{\frac{\partial S}{\partial t}+\frac{\partial D}{\partial t}}{\frac{\partial D}{\partial p}-\frac{\partial S}{\partial p}}=\frac{\varepsilon_{S}^{t}+\varepsilon_{D}^{t}}{\varepsilon_{D}^{p}-\varepsilon_{S}^{p}},
$$

where $\varepsilon_{X}^{p}$ denotes the price elasticity of demand/supply at each stage, defined as $\frac{\partial X}{\partial p} \frac{p_{r}}{D^{*}}$, where $D^{*}$ denotes the (equilibrium) quantity, $\varepsilon_{X}^{t}=\frac{\partial X}{\partial t} \frac{p_{r}}{D^{*}}$ represents evasion (quasi-)elasticities, and all elasticity terms are normalized by the same (retail) price to simplify notation. Only in the special case $\varepsilon_{S}^{t}+\varepsilon_{D}^{t}=0$ will the price not respond to a change in remittance responsibility. The textbook case assumes that both terms are zero, leading to irrelevance of the collection point.

More generally, if being a remitter is beneficial holding price constant (e.g., when it creates evasion opportunities), then both $\varepsilon_{S}^{t}$ and $\varepsilon_{D}^{t}$ are expected to be positive. As the tax responsibility is shifted to producers, their price should fall reflecting the gains that they accrue and potentially lower demand as the evasion-related gains disappear on the demand side. If having the remittance responsibility for a tax is costly (e.g., due to compliance costs), this conclusion would be reversed.

The effect on output depends on the relative responsiveness to the tax and price on either side:

$$
\frac{d D^{*}}{d t_{S}} \cdot \frac{p}{D^{*}}=\varepsilon_{D}^{p} \frac{d p}{d t_{s}}-\varepsilon_{D}^{t}=\frac{\varepsilon_{D}^{p} \varepsilon_{S}^{p}}{\varepsilon_{D}^{p}-\varepsilon_{S}^{p}}\left(\frac{\varepsilon_{S}^{t}}{\varepsilon_{S}^{p}}+\frac{\varepsilon_{D}^{t}}{\varepsilon_{D}^{p}}\right) .
$$




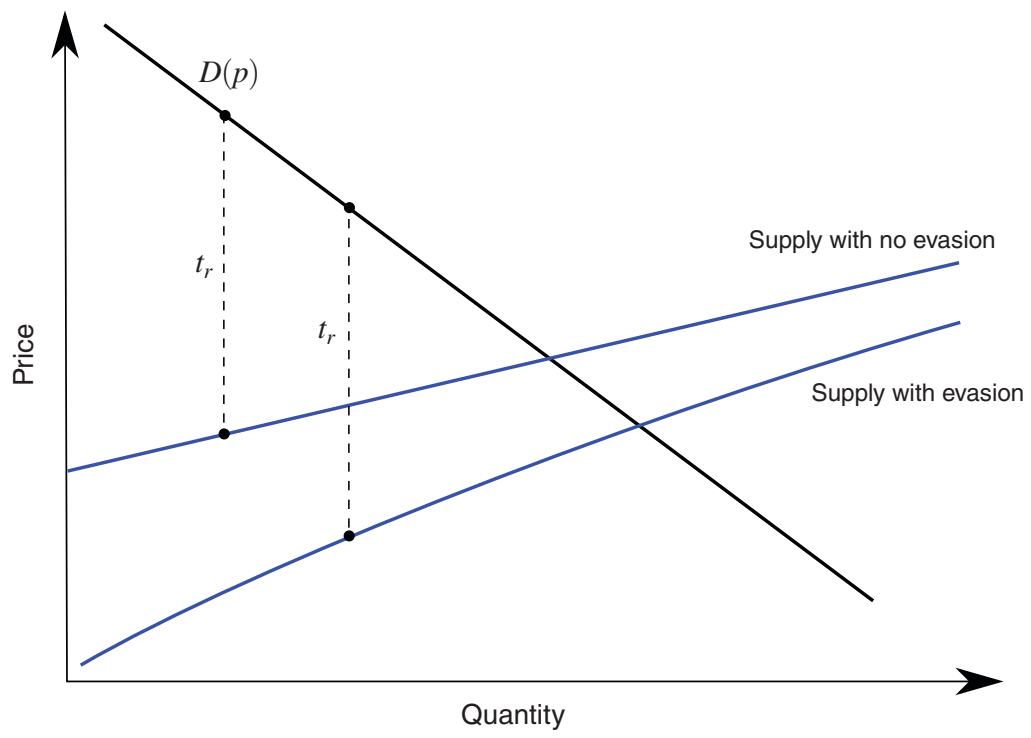

Figure 1. Equilibrium EFFEct of Tax Evasion

Assuming a positive effect of being the remitter of the tax (evasion opportunities), shifting the remittance responsibility to the relatively more tax sensitive side increases output. Only in a knife-edge case, when these relative sensitivities are the same, would the remittance regime not matter for output.

Figure 1 shows how evasion can affect the equilibrium price and output in the special case when only suppliers can evade $\left(\varepsilon_{S}^{t}>0\right.$ and $\left.\varepsilon_{D}^{t}=0\right)$. When evasion is not possible, the supply and demand curves are standard. Introducing opportunities for evasion can shift the supply curve to the right due to evasion opportunities that it affords to suppliers, leading to a new equilibrium with higher output and lower producer and consumer prices. A tax can have a smaller impact on prices in the presence of evasion (or, more generally, when the tax is collected from the side of the market more able to evade).

Moving the Point of Taxation Upstream.-Our interest in this paper is understanding the implications of changing the point of taxation. Shifting the tax from consumers to producers is a special case of this question, but in the diesel context changes took place further upstream - the point of taxation moved away from the retail sector to wholesalers and further up to the prime suppliers. To illustrate the general logic, denote by $W$ the overall supply in the wholesale industry, which depends on the price firms charge and the tax that they can evade. We will also now abstract from the possibility of evasion by final consumers. An incidence prediction may be derived by noting that the equilibrium relationship links demand and the output levels in all sectors:

$$
D\left(p_{r}^{p}+t_{r}\right)=S\left(p_{r}^{p}-p_{w}^{p}-t_{w}, t_{r}\right)=W\left(p_{w}^{p}, t_{w}\right)
$$


where $p_{r}^{p}$ and $t_{r}$ are the net-of-tax-price and the tax at the retail stage (the tax is remitted by retailers), $p_{w}^{p}$ is the net-of-tax price charged by wholesalers who also have to remit the tax of $t_{w}$, and $p_{r}^{p}-\left(p_{w}^{p}+t_{w}\right)$ is the equilibrium margin of retailers. A (marginal) shift in the point of taxation corresponds to changes in $t_{r}$ and $t_{w}$, such that $\Delta t_{r}+\Delta t_{w}=0$. Incidence predictions may be obtained by totally differentiating the two equalities with respect to $t_{r}$ and $t_{w}$ and deriving the expressions for changes in $p_{r}^{p}$ and $p_{w}^{p}$. We will focus on the effects of tax rates on the final tax-inclusive retail price $p_{r}=p_{r}^{p}+t_{r}: \frac{d p_{r}}{d t_{r}}$ and $\frac{d p_{r}}{d t_{w}}$. Straightforward manipulation yields

$$
\frac{d p_{r}}{d t_{r}}=\frac{\varepsilon_{W}^{p} \varepsilon_{S}^{p}}{\varepsilon_{S}^{p} \varepsilon_{W}^{p}-\varepsilon_{D}^{p} \varepsilon_{S}^{p}-\varepsilon_{D}^{p} \varepsilon_{W}^{p}}-\frac{\varepsilon_{W}^{p} \varepsilon_{S}^{t}}{\varepsilon_{S}^{p} \varepsilon_{W}^{p}-\varepsilon_{D}^{p} \varepsilon_{S}^{p}-\varepsilon_{D}^{p} \varepsilon_{W}^{p}}=\frac{\varepsilon_{Z}^{p}}{\varepsilon_{Z}^{p}-\varepsilon_{D}^{p}}\left(1-\frac{\varepsilon_{S}^{t}}{\varepsilon_{S}^{p}}\right)
$$

and

$$
\frac{d p_{r}}{d t_{w}}=\frac{\varepsilon_{W}^{p} \varepsilon_{S}^{p}}{\varepsilon_{S}^{p} \varepsilon_{W}^{p}-\varepsilon_{D}^{p} \varepsilon_{S}^{p}-\varepsilon_{D}^{p} \varepsilon_{W}^{p}}-\frac{\varepsilon_{S}^{p} \varepsilon_{W}^{t}}{\varepsilon_{S}^{p} \varepsilon_{W}^{p}-\varepsilon_{D}^{p} \varepsilon_{S}^{p}-\varepsilon_{D}^{p} \varepsilon_{W}^{p}}=\frac{\varepsilon_{Z}^{p}}{\varepsilon_{Z}^{p}-\varepsilon_{D}^{p}}\left(1-\frac{\varepsilon_{W}^{t}}{\varepsilon_{W}^{p}}\right),
$$

where $\varepsilon_{Z}^{p}=\frac{\varepsilon_{W}^{p} \varepsilon_{S}^{p}}{\varepsilon_{W}^{p}+\varepsilon_{S}^{p}}$ is the industry supply elasticity that accounts for its vertical structure, and the other tax and price elasticities are defined as before. The first terms in both expressions are identical and are standard price responses to tax at the production stage accounting for the usual elasticities in the two upstream production sectors. The second tax terms are new and reflect the impact of the statutory tax that is not remitted and therefore is not reflected in the price (in particular, potentially due to the evasion channel). The response to the tax at a given stage reflects the effect of the tax on supply at that particular stage with tax evasion opportunities simply attenuating the response to the tax.

Note that these incidence effects correspond to the point made in Slemrod and Kopczuk (2002) that tax elasticities may be a function of administrative parameters: here, the response of the equilibrium price $p_{r}$, and hence the response of equilibrium output $D\left(p_{r}\right)$, depends on whether the total tax rate $t_{r}+t_{w}$ is collected as $t_{r}$ or $t_{w}$ is-a decision about remittance responsibility that has no consequences in the standard model.

The incidence implication of shifting the remittance responsibility corresponds to considering $\Delta t_{r}+\Delta t_{w}=0$, so that the effect on the final price is simply $\Delta t_{r} \cdot\left(\frac{d p_{r}}{d t_{r}}-\frac{d p_{r}}{d t_{w}}\right)$. Combining the terms yields

$$
\frac{d p_{r}}{d t_{r}}-\frac{d p_{r}}{d t_{w}}=\frac{\varepsilon_{Z}^{p}}{\varepsilon_{Z}^{p}-\varepsilon_{D}^{p}} \cdot\left(\frac{\varepsilon_{W}^{t}}{\varepsilon_{W}^{p}}-\frac{\varepsilon_{S}^{t}}{\varepsilon_{S}^{p}}\right)
$$

In the special case when the evasion channel is not present, $\varepsilon_{W}^{t}=\varepsilon_{S}^{t}=0$ and we are back to the standard incidence result. In the knife-edge case when $\frac{\varepsilon_{W}^{t}}{\varepsilon_{W}^{p}}=\frac{\varepsilon_{S}^{t}}{\varepsilon_{S}^{p}}$, so that evasion response is the same proportion of the supply response in each sector, 
the invariance result also happens to hold. In general, when the evasion response varies across sectors, shifts in remittance responsibility will have implications for the final price. Shifting the tax remittance responsibility to the sector with less tax-elastic evasion results in higher pass-through of the tax.

Because we assumed away tax evasion by consumers, the overall effect on output in the industry $D\left(p_{r}\right)$ simply follows from the response of the retail price $p_{r}$ as $\Delta t_{r} \cdot D^{\prime}\left(p_{r}\right)\left(\frac{d p_{r}}{d t_{r}}-\frac{d p_{r}}{d t_{w}}\right)$, so that higher pass through due to shifting the point of taxation to the less evasion-prone sector implies higher loss of output.

Of particular interest is the response of the overall taxable quantity (and, correspondingly, tax collections) to shifts in tax incidence. Denoting, by $E_{S}$ and $E_{W}$ the overall tax evasion in the two sectors, we are interested in $T\left(p_{r}, t_{r}, t_{w}\right)$ $=D\left(p_{r}\right)-E_{S}\left(p_{r}^{p}-p_{w}^{p}-t_{w}, t_{r}\right)-E_{W}\left(p_{w}^{p}, t_{w}\right)$. The effect of a shift in tax remittance by $\Delta t_{r}=-\Delta t_{w}$ affects overall output through the price channel, as previously discussed, and it affects tax evasion in the two sectors. In the working paper version of this paper we formally analyzed a model where the individual firm's cost of output and evasion are separable, i.e., $C(q, e)=C_{1}(q)+C_{2}(e)$, so that the firm's level of evasion does not depend on the price but only on its tax rate. Even in that simple case, the effect of a shift in remittance responsibility on taxable quantity cannot be unambiguously signed. This is because a shift in remittance responsibility works on two different margins in determining tax evasion: it affects tax evasion decisions of existing firms, and it determines entry of new firms. In this special case, it is the entry/exit margin that is solely responsible for the supply responses that determine incidence (the key comparison was between $\frac{\varepsilon_{W}^{t}}{\varepsilon_{W}^{p}}$ and $\frac{\varepsilon_{S}^{t}}{\varepsilon_{S}^{p}}$ ), because the separability assumption implies that the output of existing firms is not affected by remittance responsibility. However, tax evasion of existing firms is affected by remittance responsibility. In general, the exit/entry margin may be very responsive (it is determined by the density of marginal firms) without evasion of inframarginal firms being responsive (because it is determined by technology of evasion), or vice versa. As the result, there is no unambiguous connection between the direction of incidence effects and tax base effects. Naturally though, the sensitivity of the tax base to shifts in the point of collection is not consistent with a standard model, but it is consistent with the presence of tax evasion.

We turn now to an empirical analysis of the effect of taxation on the diesel fuel market. We first discuss some key institutional details, the data we examine, and the methods we employ, and finally the results of our analyses.

\section{Institutional Details}

\section{A. The Diesel Supply Chain and Tax Remittance}

The empirical context examined in this paper is taxation of diesel fuel. Oil refineries distill crude oil into constituent products one of which is No. 2 distillate, the general term describing diesel fuel. After distillation, diesel fuel is further processed to meet regulatory standards dictating sulfur content, which vary depending on 


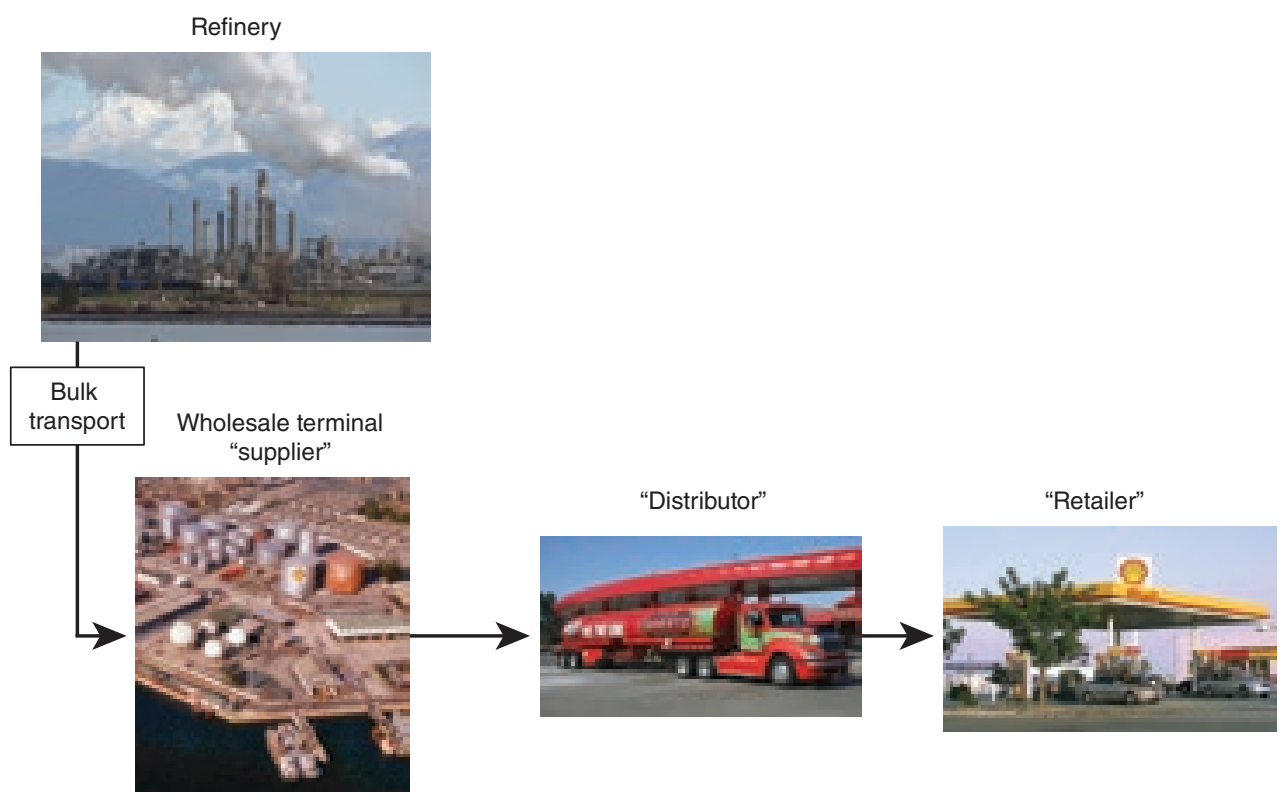

Figure 2. Diesel Fuel Supply Chain

Source:

Refinery—https://commons.wikimedia.org/wiki/File:Anacortes_Refinery_31911.JPG

Terminal—https://commons.wikimedia.org/wiki/File:HK_Shell_depot.JPG

Distributor—https://commons.wikimedia.org/wiki/File:2011-01-28_Sheetz_tank_truck.jpg

Retailer-https://commons.wikimedia.org/wiki/File:Shellgasstationlosthills.jpg

location of eventual sale, season, and intended use. ${ }^{6}$ The final product is shipped by pipeline or barge to bulk terminals "suppliers" located near most major metropolitan areas. At bulk terminals, it is purchased by wholesale "distributors," who deliver diesel by tanker truck to retail outlets, "retailers," and larger scale end users such as trucking companies. Figure 2 illustrates the supply chain for diesel fuel.

The primary use of diesel fuel is to power vehicle diesel combustion engines in commercial vehicles. Diesel intended for highway use is subject to federal taxes of 24.4 cents per gallon and state taxes that currently range from 8 to 35.1 cents per gallon. Federal fuel taxes are the primary source of revenue for the Federal Highway Trust, which funds infrastructure investment. Diesel fuel is equivalent chemically to No. 2 distillate "fuel oil" used for home heating and industrial processes, aside from regulated variation in sulfur content. Fuel oil is not subject to federal, state, or local on-highway diesel taxes nor is diesel fuel meant for off-highway (e.g., farming) use.

Federal and state diesel taxes are collected at some point in the local supply chain (between the "supplier" and "retailer"). Our empirical strategy will rely on panel variation in the identity of the party responsible for the remittance of on-highway

\footnotetext{
${ }^{6}$ From October 1993 to August 2006, the allowable sulfur content for on-highway diesel fuel was 500 parts per million (ppm). Federal regulations did not constrain the sulfur content of diesel intended for other uses. Beginning September 1, 2006, the EPA began phasing in Ultra Low Sulfur Diesel Fuel requirements, requiring that sulfur content not exceed 15 ppm. By 2010 all diesel sold for on-highway use met this standard. Non-road diesel was required to move to $500 \mathrm{ppm}$ in 2007, and the $15 \mathrm{ppm}$ standard is currently being phased in.
} 
taxes. In general, the point of tax collection has moved up the supply chain over time. Prior to 1988, Federal tax collection occurred at the retail level. In 1988, the point of taxation was moved to the wholesale distributor level, and in 1994 the responsibility for remittance was shifted again to its current location at the supplier level. There has also been considerable variation in the point of collection for state diesel taxes, both across states and over time, which we exploit in our empirical analysis that follows.

\section{B. Fuel Tax Evasion and Avoidance}

Several characteristics of the market for diesel and the method of tax collection affect the opportunities for tax evasion and therefore how remittance can impact tax incidence. With a few exceptions, evasion can generally be grouped into one of three categories: the misreporting of the intended use of fuel, not remitting owed taxes, and bootlegging.

An incentive to misreport exists because diesel is taxed differentially depending on use. On-highway use is subject to state and federal taxes, but diesel used for home heating, industry, or agriculture is untaxed. Because both taxable and nontaxable uses are significant sources of demand for diesel, 7 prime suppliers, and distributors responsible for tax remittance may be able to credibly misreport diesel sold to retail stations as being for untaxed use. Historical evidence, documented in Marion and Muehlegger (2008), suggests that misreporting reduced tax revenues by 25-30 percent prior to the introduction of red dye for untaxed diesel fuel. ${ }^{8}$

Some evasion of this type is done by end users who consume both taxed and untaxed fuel. To this extent, the placement of statutory incidence in the supply chain is not relevant. Large-scale schemes, where wholesalers purchase fuel oil and sell this to retail outlets as on-highway diesel, presumably would be curtailed by retail collection.

A second form of evasion involves an incurred tax liability that is not remitted to the government. This is most likely to occur at the retailer or distributor level. Simple underreporting is one possible issue. Another classic example is the "daisy chain," which is sometimes observed when the distributor is responsible for remitting the tax. Under this scheme a gallon of diesel is sold by the prime supplier to the wholesale distributor, who then sells it to other dummy distributors in a series of (likely paper-only) transactions. At some point the gallon is sold to a retail station, and the party responsible for remitting the tax "disappears."

\footnotetext{
${ }^{7}$ According to data from the Energy Information Administration, in 2004, 59.6 percent of distillate sales to end users were retail sales for on-highway use.

${ }^{8}$ Beginning in October 1993, terminals were required to add red dye to diesel fuel sold for untaxed off-highway use. This allowed for a simple visual inspection to verify that taxes had been paid on a particular gallon-a truck with red diesel in its gas tank was evading taxes. In the month the dye program began, reported sales of diesel for use on-highway rose by 25-30 percent, with a corresponding decline in reported sales for untaxed uses. Although the dye program was initially highly successful at curtailing this form of evasion, several new techniques have been employed by evaders to skirt the dyeing regulations. In particular, evaders have been found offloading fuel without injecting dye, removing dye from the fuel, and/or masking the dye's color. Also, misreporting the fuel's intended use may still be an issue in some circumstances, as states allow for refunds of the tax remitted if the user later claims the fuel was used for untaxed purchases. This is often true in agriculture uses.
} 
Moving the point of taxation up the supply chain reduces the number of parties with a tax liability. According to the Internal Revenue Service, there are 1,343 active bulk fuel terminals in the United States, compared with 855,915 retail gasoline station establishments reported in the County Business Patterns. As discussed by Baluch (1996) and Weimar et al. (2008), tax authorities and policy analysts believe that tax enforcement is substantially easier when the tax is remitted by parties higher in the supply chain, by virtue of there being fewer parties, and more costly or more easily detectable methods of evasion.

A third type of evasion exploits differential rates of taxation between jurisdictions. Bootlegging is one example, where purchases are made by a distributor in a low-tax state, and then sold to retailers in a neighboring high-tax state at a higher price that reflects the tax rate in place. A second example involves a distributor that purchases fuel from a supplier claiming it is intended for export to another state and thereby not subject to the state tax. Rather than exporting, the firm then sells it to a within-state retail station.

Trucking companies pay state diesel taxes based on miles driven in each state. An interstate trucker submits a tax return to the International Fuel Tax Agreement (IFTA) that states the miles driven by state and is then credited or taxed based on the difference between the tax owed and tax already paid. This creates an incentive to understate total miles driven, and also to overstate miles driven in low tax states.

Interjurisdictional evasion also arises through Native American reservations. As a result of tribal sovereignty, foreign imports to a reservation are not tracked by the federal government or state governments. Imported gallons can then be diverted to retail stations outside the reservation.

Finally, it is also possible to illicitly import untaxed fuel from abroad, subsequently selling the fuel to retail stations. With the exception of IFTA evasion by truckers, most forms of interjurisdictional methods for evasion are curtailed by placing the responsibility of remittance at the retail level, which makes the state of sale more easily verified.

Despite the fact that different strategies for evasion exist throughout the supply chain, the institutional details suggest that, on balance, the opportunities for evasion should be less when the remitting party is upstream rather than downstream. ${ }^{9}$ Consequently, we should expect higher rates of pass-through when the tax is collected from suppliers. Since the introduction of fuel dye, most of the opportunities for evasion exist downstream of the wholesale terminal, at either the distributor or retailer level. Moreover, wholesalers are typically major oil brands with operations

\footnotetext{
${ }^{9}$ This is corroborated by the assessment of policy briefs (see, e.g., "Report to the Congress on Evasion of the Federal Gasoline Tax," Office of Tax Policy December 1987, and "Identifying and Quantifying Rates of States' Motor Fuel Tax Evasion," Transportation Research Board 2008) that note that moving the point of taxation upstream minimizes opportunities for fuel tax evasion and that improving fuel tax enforcement was a major motivation for the federal government when the point of collection for federal diesel taxes was moved up to the terminal. Prior to the shift, the Office of Tax Policy noted "The Administration has concluded that there is a need to change the point at which Federal excise tax on diesel fuel is levied. The potential for tax evasion and other forms of noncompliance can be minimized only if the point at which the tax is imposed is moved closer to the beginning of the distribution stream." Transportation Research Board echoed this belief "Taxing at the terminal rack for motor fuels is widely accepted as one key measure a government can take towards increasing motor fuel excise tax compliance. Moving the point of taxation to the terminal rack decreases the opportunities for downstream tax evasion and greatly reduces the number of taxpayers, decreasing the administrative and enforcement burden on collection agencies."
} 
in many states, while distributors and retail stations are smaller, more numerous, and ownership is less concentrated. If detection of illegal activity is easier or close scrutiny less costly, evasion opportunities at the wholesale terminal may be further curtailed. Finally, opportunities for entry likely differ. Entry and exit are relatively easy at the distributor and retail level relative to at the terminal level, where entry may face constraints related to permitting and siting, which means that rents from evasion are less likely to be competed away at the prime supplier level. All three would tend to increase pass-through of a tax remitted by terminal owners relative to a tax remitted further downstream.

\section{Data and Methodology}

To this point we have argued that the pass-through rate of a tax to the retail price can, in a setting where evasion is important, depend on the location of tax remittance responsibility. We now proceed to examine the evidence for this hypothesis in the diesel fuel market.

\section{A. Data}

We collected data on the point of tax collection from successive annual issues of "Highway Taxes and Fees: How They Are Collected and Distributed," published by the Federal Highway Adminstration. For each state and year, the Federal Highway Administration contacts state tax authorities and collects data on the point of collection for diesel and gasoline taxes.

In Figure 3, we display the variation in the point of taxation over time. In the mid-eighties, the majority of states collected taxes from distributors. At the beginning of our sample in 1986, distributors were responsible for remittance in 37 states, with the balance of states collecting from retailers. The early nineties saw a trend toward collecting taxes from higher points in the supply chain, in particular from the prime supplier. In January 1993, Michigan became the first state to do so, and by the end of 2006, 20 states collected taxes from prime suppliers. While a plurality of states still collect from wholesale distributors, the practice of collecting from retailers has been almost entirely phased out, with only New Jersey and Oregon collecting tax from retailers at the end of our sample in 2006. ${ }^{10}$

In Figure 4, we present maps of the variation in the point of tax collection across states for 1990, 1997, and 2004. ${ }^{11}$ In 1990, the entire eastern section of the United States collected taxes from the distributor. The collection of taxes at the retail level was concentrated in Midwestern and Western states. Panels B and C describe the geographic characteristics of the transition to taxing at higher levels of the supply chain. During this time, the West, Midwest, and mid-Atlantic transitioned largely toward collecting diesel taxes from terminal operators. Collection at the distributor

\footnotetext{
${ }^{10}$ Oregon is a special case. There, diesel used for trucking is not taxed directly, and instead a levy on weightmiles driven within the state is collected. Given the importance of trucking in the diesel market, we will in general exclude Oregon from the analysis.

${ }^{11}$ Darker shading corresponds to further upstream tax collection. The lightest shade corresponds to states that collect from retailers. The darkest states collect taxes from the wholesale terminal operators.
} 


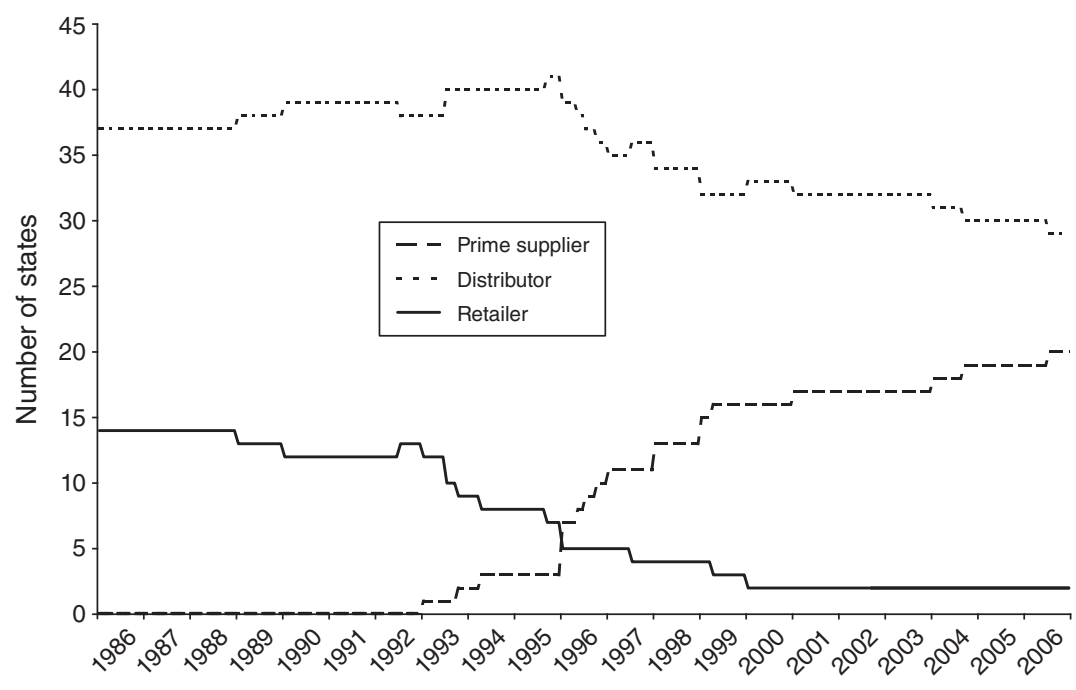

Figure 3. Diesel Fuel Supply Chain

Note: The y-axis denotes the number of states collecting state diesel fuel taxes from retailers (solid line), the distributor (dotted line), and the terminal/prime supplier (dashed line) at the end of each calendar year.

level was concentrated in the northeast, south, and mountain states. An interesting observation from this figure is that the point-of-collection policy seems to be spatially correlated, which suggests that there are spillovers of some kind across states in tax collection.

In Table 1, we further describe the nature of the variation in tax collection by showing the matrix of changes in point of collection. We observe 29 changes in the point of tax collection, of which 28 move the point of collection upstream. Eight of these are changes from retailer collection to distributor collection, 5 are retailer to supplier shifts, and 15 are distributor to supplier shifts. Only one state, New Jersey, moves the point of collection downstream, from the distributor level to retail outlets.

Several monthly diesel price series are available at the state level from the Energy Information Administration (EIA). The EIA reports diesel prices for select states, mostly comprising states in the Northeast, mid-Atlantic, Upper Midwest, and a handful of Northwestern states with relatively high use of home heating oil. Beginning in 1983, the EIA reports an average price of No. 2 distillate, which includes taxed diesel fuel, untaxed diesel fuel, and heating oil. It distinguishes between diesel sold through retail outlets and that sold for resale. However, the resale price can include sales by prime suppliers to local distributors, or from local distributors to retail stations, which will pose a disadvantage in assessing how tax collection affects how retail stations share the tax burden with distributors, or distributors with prime suppliers. Furthermore, prior to 1994, the resale price of No. 2 distillate also included untaxed sales of diesel.

From 1994 on, the EIA also reports the average retail and resale prices specifically of No. 2 diesel. This distinction is irrelevant for sales through retail outlets, as only diesel fuel is sold through retail outlets. During the period of time when the 


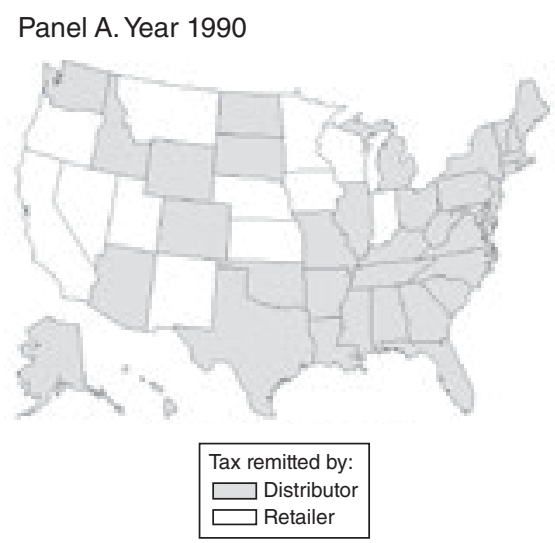

Panel B. Year 1997

Panel C. Year 2004
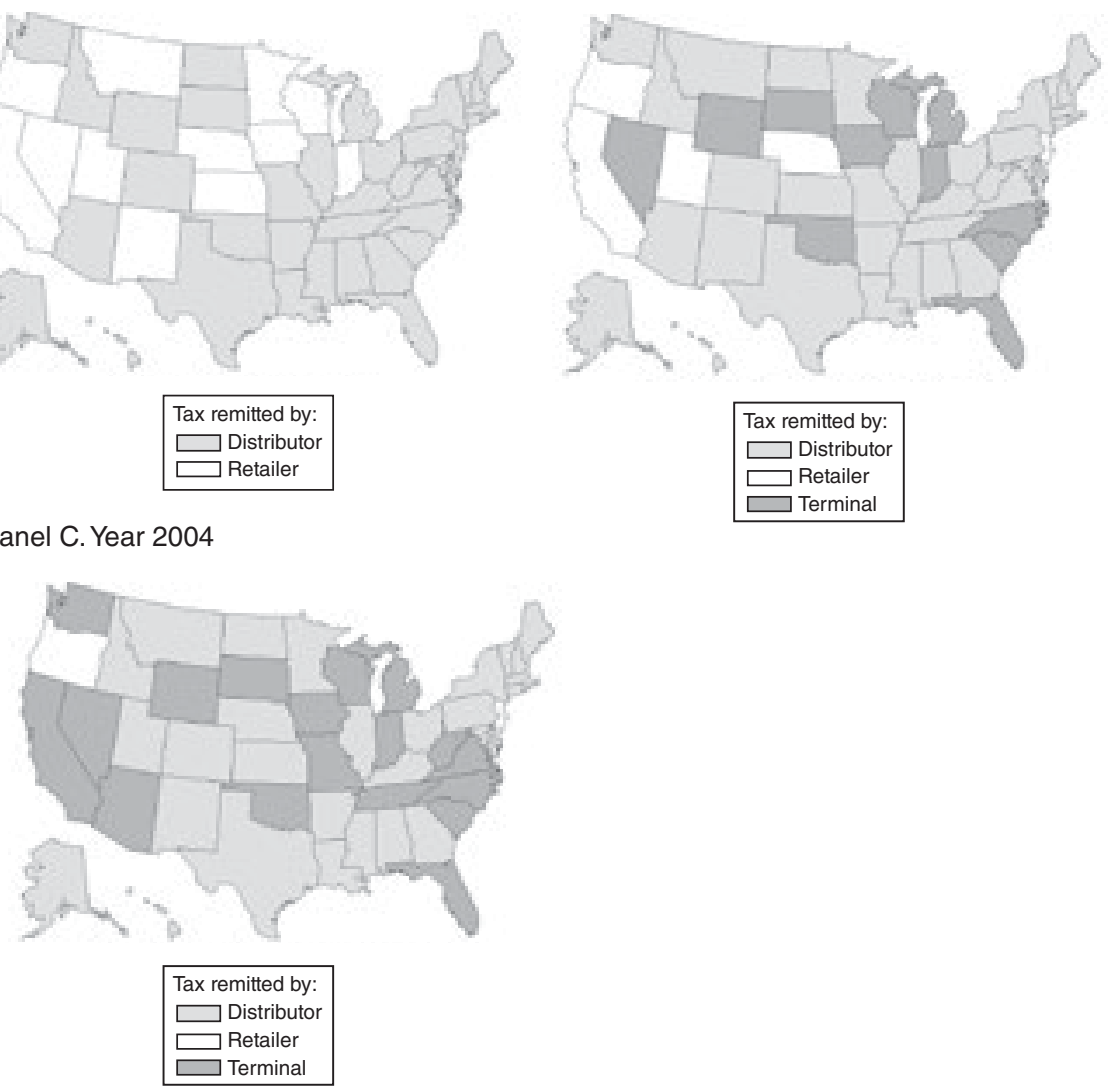

Figure 4. Tax Collection by State

Note: White, light grey, and dark grey shades correspond to retailer-remittance, distributor-remittance, and terminal-remittance, respectively.

Table 1 - Transitions in the Point of Tax Collection

\begin{tabular}{llccc}
\hline \hline & & \multicolumn{2}{c}{ To: } \\
\cline { 3 - 5 } & & Retailer & Distributor & Supplier \\
\hline \multirow{3}{*}{ From: } & Retailer & - & 8 & 5 \\
& Distributor & 1 & - & 15 \\
& Supplier & 0 & 0 & - \\
\hline
\end{tabular}

series overlap (from 1994 on), the retail prices for No. 2 distillate and diesel fuel are identical. On the other hand, resale of No. 2 distillate can include transactions for on-highway diesel, heating oil, or other uses of distillate. Therefore, the series describing the resale prices of No. 2 distillate and No. 2 diesel are not perfect substitutes. The two series move in lock-step $(\rho=0.994)$, but the resale price for No. 2 distillate averages 1.4 cents per gallon less than the resale price for diesel fuel. For these reasons, we focus our attention in this paper on the retail price of No. 2 diesel. 
We have argued that how remittance affects incidence depends on its effect on tax evasion opportunities. To measure how tax remittance may affect tax collection and evasion opportunities, we obtain data on diesel tax collections from two separate sources. The most accurate measure comes from the Federal Highway Administration, which reports the annual quantity by state of special fuels on which taxes were collected in Table MF-2 of the Highway Statistics Annual. Taxed special fuels are almost entirely diesel fuel. Beginning in 1983, the EIA also reports monthly data from a survey of prime suppliers, who distinguish sales of No. 2 diesel and heating oil by state. What level of the supply chain the EIA treats as the prime supplier for the purposes of reporting depends on whether the fuel is imported from another jurisdiction. For fuel distilled in the state of eventual sale to the end user, the prime supplier is the bulk terminal. For distilled fuel imported from another state or country, the prime supplier is considered to be the first distributor within the state who receives the fuel. We obtain information about the federal and state on-road diesel tax rates from 1981 to 2006 from the Federal Highway Administration Annual Highway Statistics.

We also collect data on state-level covariates. Population, per capita income, and mean family size are obtained from the Census Bureau. Urbanization and educational attainment are taken from the Bureau of Economic Analysis. Information about drivers, vehicle registration, and vehicle usage are from successive issues of Highway Statistics produced by the Federal Highway Adminstration.

We recognize that the point of taxation is unlikely to be chosen randomly. To investigate this issue, in Table 2, we present the mean differences of a variety of demographic characteristics between retailer, distributor, and supplier-remitting states. Each column in a particular panel shows a regression of the stated variable on distributor and supplier-remit dummies, as well as year fixed effects. ${ }^{12}$ The results shown in Table 2 suggest that the point of taxation is correlated with few of the covariates. Compared with retailer-remitting states, those that tax at the supplier level tend to have a less-educated adult population and are less conservative politically. Those taxing at the distributor level also have a somewhat less educated population than retailer-remitting states, and have a smaller budget surplus, and both the upper and lower state houses have a slightly higher portion of Democrats. However, income, unemployment, population, urbanization, vehicle miles traveled per capita, and the share of gross state product attributable to the manufacturing, mining, farming, petroleum, and trucking industries are all similar across states under the three collection regimes.

We also conduct two other exercises examining the potential endogeneity of remittance policy. First, in Table 3, we examine whether states that change the point of collection at some point in the sample are different than those who leave the point of collection unchanged. Only a state's mining share of Gross State Product and the conservative-values score of the state house of representatives are significant at the 10 percent level.

\footnotetext{
${ }^{12}$ Many of the variables in this table are not included in the set of covariates in the regression specifications later, because variables such as population, urban population share, and the percent of population that are BA graduates are slow-moving, and most of their variation will be captured by state fixed effects.
} 
Table 2-Demographics and the Point of Tax Collection

\begin{tabular}{|c|c|c|c|c|c|c|c|}
\hline & $\begin{array}{l}\text { Tax-excl. } \\
\text { diesel price }\end{array}$ & $\begin{array}{l}\text { State diesel } \\
\operatorname{tax}(\mathrm{cpg})\end{array}$ & $\begin{array}{c}\text { GSP share } \\
\text { manufacturing }\end{array}$ & $\begin{array}{l}\text { GSP share } \\
\text { mining }\end{array}$ & $\begin{array}{l}\text { GSP share } \\
\text { farming }\end{array}$ & $\begin{array}{l}\text { GSP share } \\
\text { petroleum }\end{array}$ & $\begin{array}{c}\text { GSP share } \\
\text { trucking }\end{array}$ \\
\hline \multicolumn{8}{|l|}{ Panel A } \\
\hline $\begin{array}{l}\text { Distributor- } \\
\text { remittance }\end{array}$ & $\begin{array}{l}2.966^{*} \\
(1.722)\end{array}$ & $\begin{array}{c}-0.829 \\
(1.254)\end{array}$ & $\begin{array}{c}0.0111 \\
(0.0193)\end{array}$ & $\begin{array}{c}0.0105 \\
(0.0103)\end{array}$ & $\begin{array}{c}-0.00783 \\
(0.00687)\end{array}$ & $\begin{array}{c}0.00126 \\
(0.00158)\end{array}$ & $\begin{array}{c}-0.00229 \\
(0.00152)\end{array}$ \\
\hline $\begin{array}{l}\text { Supplier- } \\
\text { remittance }\end{array}$ & $\begin{array}{c}-1.612 \\
(2.469)\end{array}$ & $\begin{array}{c}-1.641 \\
(1.705)\end{array}$ & $\begin{array}{c}0.0398 * \\
(0.0219)\end{array}$ & $\begin{array}{c}0.0138 \\
(0.0193)\end{array}$ & $\begin{array}{c}-0.00553 \\
(0.00823)\end{array}$ & $\begin{array}{c}-0.00133 \\
(0.00173)\end{array}$ & $\begin{array}{c}-0.000722 \\
(0.00187)\end{array}$ \\
\hline Constant & $\begin{array}{c}111.6 * * * \\
(1.309)\end{array}$ & $\begin{array}{l}20.16 * * * \\
(1.138)\end{array}$ & $\begin{array}{l}0.144 * * * \\
(0.0166)\end{array}$ & $\begin{array}{r}0.0154 * * \\
(0.00632)\end{array}$ & $\begin{array}{l}0.0225 * * * \\
(0.00607)\end{array}$ & $\begin{array}{l}0.00497 \text { *** } \\
(0.00116)\end{array}$ & $\begin{array}{l}0.0144 * * * \\
(0.00141)\end{array}$ \\
\hline \multirow[t]{2}{*}{$\begin{array}{l}\text { Observations } \\
R^{2}\end{array}$} & $\begin{array}{c}6,091 \\
0.990\end{array}$ & $\begin{array}{c}13,536 \\
0.207\end{array}$ & $\begin{array}{l}13,536 \\
0.198\end{array}$ & $\begin{array}{l}13,536 \\
0.0165\end{array}$ & $\begin{array}{l}13,536 \\
0.0622\end{array}$ & $\begin{array}{l}13,356 \\
0.0439\end{array}$ & $\begin{array}{l}13,536 \\
0.133\end{array}$ \\
\hline & Population & $\begin{array}{l}\text { GSP per } \\
\text { capita }\end{array}$ & $\begin{array}{l}\text { Unemployment } \\
\text { rate }\end{array}$ & $\begin{array}{l}\text { Urban pop. } \\
\text { share }\end{array}$ & $\begin{array}{c}\text { Fraction of } \\
\text { adults with BA }\end{array}$ & $\begin{array}{c}\text { Fraction of } \\
\text { adults grad. HS }\end{array}$ & $\begin{array}{l}\text { Vehicle miles } \\
\text { trav. per capita }\end{array}$ \\
\hline \multicolumn{8}{|l|}{ Panel B } \\
\hline $\begin{array}{l}\text { Distributor- } \\
\text { remittance }\end{array}$ & $\begin{array}{c}-0.940 \\
(1.843)\end{array}$ & $\begin{array}{c}-871.0 \\
(1,170.7)\end{array}$ & $\begin{array}{c}0.523 \\
(0.369)\end{array}$ & $\begin{array}{c}-0.0347 \\
(0.0549)\end{array}$ & $\begin{array}{c}-0.796 \\
(1.006)\end{array}$ & $\begin{array}{l}-4.086 * * * \\
(1.181)\end{array}$ & $\begin{array}{c}0.000430 \\
(0.000436)\end{array}$ \\
\hline $\begin{array}{l}\text { Supplier- } \\
\text { remittance }\end{array}$ & $\begin{array}{c}0.486 \\
(1.413)\end{array}$ & $\begin{array}{c}-1,432.5 \\
(1,515.1)\end{array}$ & $\begin{array}{c}0.314 \\
(0.393)\end{array}$ & $\begin{array}{c}-0.0291 \\
(0.0697)\end{array}$ & $\begin{array}{l}-3.522 * * * \\
(0.884)\end{array}$ & $\begin{array}{l}-4.056^{* * * *} \\
(1.432)\end{array}$ & $\begin{array}{c}0.00124 \\
(0.000805)\end{array}$ \\
\hline Constant & $\begin{array}{l}4.686 * * * \\
(1.718)\end{array}$ & $\begin{array}{l}30,337.2 * * * \\
(1,064.5)\end{array}$ & $\begin{array}{l}4.889 * * * \\
(0.310)\end{array}$ & $\begin{array}{l}0.750 * * * \\
(0.0485)\end{array}$ & $\begin{array}{l}23.56 * * * \\
(0.741)\end{array}$ & $\begin{array}{l}83.07 * * * \\
(0.866)\end{array}$ & $\begin{array}{c}0.0128 * * * \\
(0.000394)\end{array}$ \\
\hline \multirow[t]{2}{*}{$\begin{array}{l}\text { Observations } \\
R^{2}\end{array}$} & $\begin{array}{l}13,248 \\
0.0205\end{array}$ & $\begin{array}{c}13,248 \\
0.709\end{array}$ & $\begin{array}{l}13,536 \\
0.311\end{array}$ & $\begin{array}{l}13,248 \\
0.00524\end{array}$ & $\begin{array}{l}13,248 \\
0.333\end{array}$ & $\begin{array}{l}13,248 \\
0.462\end{array}$ & $\begin{array}{l}13,248 \\
0.196\end{array}$ \\
\hline & $\begin{array}{c}\text { Percent state } \\
\text { budget surplus }\end{array}$ & $\begin{array}{l}\text { Senator } \\
\text { LCV score }\end{array}$ & $\begin{array}{c}\text { House } \\
\text { LCV score }\end{array}$ & $\begin{array}{l}\text { Democrat } \\
\text { governor }\end{array}$ & $\begin{array}{l}\text { Dem. fraction } \\
\text { state senate }\end{array}$ & $\begin{array}{l}\text { Dem. fraction } \\
\text { of state house }\end{array}$ & \\
\hline \multicolumn{8}{|l|}{ Panel C } \\
\hline $\begin{array}{l}\text { Distributor- } \\
\text { remittance }\end{array}$ & $\begin{array}{c}-0.0284 * \\
(0.0147)\end{array}$ & $\begin{array}{c}-5.872 \\
(7.455)\end{array}$ & $\begin{array}{c}-1.142 \\
(5.586)\end{array}$ & $\begin{array}{l}0.0316 \\
(0.126)\end{array}$ & $\begin{array}{l}0.100 * * * \\
(0.0343)\end{array}$ & $\begin{array}{l}0.0804 * * \\
(0.0334)\end{array}$ & \\
\hline $\begin{array}{l}\text { Supplier- } \\
\text { remittance }\end{array}$ & $\begin{array}{c}-0.0112 \\
(0.0215)\end{array}$ & $\begin{array}{l}-8.150 \\
(10.13)\end{array}$ & $\begin{array}{r}-12.78^{*} \\
(7.592)\end{array}$ & $\begin{array}{c}0.191 \\
(0.162)\end{array}$ & $\begin{array}{c}0.0339 \\
(0.0392)\end{array}$ & $\begin{array}{c}0.0190 \\
(0.0356)\end{array}$ & \\
\hline Constant & $\begin{array}{l}0.113 * * * \\
(0.0120)\end{array}$ & $\begin{array}{l}52.56 * * * \\
(6.595)\end{array}$ & $\begin{array}{l}48.23 * * * \\
(4.892)\end{array}$ & $\begin{array}{l}0.414 * * * \\
(0.112)\end{array}$ & $\begin{array}{c}0.476 * * * \\
(0.0258)\end{array}$ & $\begin{array}{l}0.492 * * * \\
(0.0222)\end{array}$ & \\
\hline Observations & 12,672 & 13,248 & 13,248 & 13,440 & 13,020 & 12,984 & \\
\hline$R^{2}$ & 0.475 & 0.0201 & 0.120 & 0.0539 & 0.132 & 0.105 & \\
\hline
\end{tabular}

Notes: The dependent variable of each regression is listed in the panel header rows. The unit of observation is the state-month level. Retailer-remittance is the omitted category. All regressions include year fixed effects. Standard errors clustered by state.

*** Significant at the 1 percent level.

** Significant at the 5 percent level.

* Significant at the 10 percent level.

Second, we wish to consider which covariates may be contemporaneously correlated with changes in either the point of tax collection or the diesel tax rate. In the first three columns of Table 4, we regress the change in the distributor-remit, retailer-remit, and supplier-remit dummy variables, on a set of first-differenced covariates and year fixed effects. We find little evidence of systematic determinants of the changes in tax regimes, but cannot rule out decisively that there are unmeasured determinants. ${ }^{13}$ In column 4, we examine contemporaneous correlation

\footnotetext{
${ }^{13}$ Above average population growth is positively related with a shift to supplier remittance, though negatively correlated with a shift to distributor remittance. Similarly, above average growth in the mining industry is negatively correlated with a shift to distributor-remittance.
} 
Table 3-Summary Statistics by Change in Point of Diesel Tax Collection

\begin{tabular}{|c|c|c|c|c|}
\hline & $\begin{array}{c}\text { Full } \\
\text { sample }\end{array}$ & $\begin{array}{c}\text { States not } \\
\text { changing POT }\end{array}$ & $\begin{array}{c}\text { States } \\
\text { changing POT }\end{array}$ & Difference \\
\hline Tax-excl. diesel price & $\begin{array}{c}95.97 \\
(43.77)\end{array}$ & $\begin{array}{c}97.88 \\
(44.22)\end{array}$ & $\begin{array}{c}93.20 \\
(42.97)\end{array}$ & $-4.67 *$ \\
\hline State diesel tax (cpg) & $\begin{array}{l}19.12 \\
(5.026)\end{array}$ & $\begin{array}{l}19.24 \\
(5.278)\end{array}$ & $\begin{array}{l}19.03 \\
(4.828)\end{array}$ & -0.21 \\
\hline GSP per capita & $\begin{array}{c}28,153.9 \\
(8,784.1)\end{array}$ & $\begin{array}{c}28,392.8 \\
(9,560.0)\end{array}$ & $\begin{array}{l}27,983.3 \\
(8,181.5)\end{array}$ & -409.5 \\
\hline Unemployment rate (percent) & $\begin{array}{c}5.307 \\
(1.555)\end{array}$ & $\begin{array}{c}5.255 \\
(1.487)\end{array}$ & $\begin{array}{c}5.346 \\
(1.602)\end{array}$ & 0.091 \\
\hline GSP share-manufacturing & $\begin{array}{c}0.162 \\
(0.068)\end{array}$ & $\begin{array}{c}0.166 \\
(0.064)\end{array}$ & $\begin{array}{c}0.158 \\
(0.070)\end{array}$ & -0.008 \\
\hline GSP share-mining & $\begin{array}{c}0.024 \\
(0.050)\end{array}$ & $\begin{array}{c}0.010 \\
(0.024)\end{array}$ & $\begin{array}{c}0.033 \\
(0.061)\end{array}$ & $0.23^{*}$ \\
\hline GSP share_farming & $\begin{array}{c}0.0170 \\
(0.020)\end{array}$ & $\begin{array}{c}0.0154 \\
(0.019)\end{array}$ & $\begin{array}{c}0.0182 \\
(0.021)\end{array}$ & 0.003 \\
\hline GSP share-petroleum & $\begin{array}{c}0.005 \\
(0.011)\end{array}$ & $\begin{array}{c}0.0036 \\
(0.005)\end{array}$ & $\begin{array}{c}0.0063 \\
(0.014)\end{array}$ & 0.003 \\
\hline GSP share-trucking & $\begin{array}{c}0.013 \\
(0.006)\end{array}$ & $\begin{array}{c}0.012 \\
(0.006)\end{array}$ & $\begin{array}{c}0.014 \\
(0.005)\end{array}$ & 0.001 \\
\hline Population (millions) & $\begin{array}{c}4.135 \\
(4.377)\end{array}$ & $\begin{array}{c}3.179 \\
(2.776)\end{array}$ & $\begin{array}{c}4.817 \\
(5.120)\end{array}$ & 1.638 \\
\hline Urban population share & $\begin{array}{c}0.722 \\
(0.188)\end{array}$ & $\begin{array}{c}0.719 \\
(0.194)\end{array}$ & $\begin{array}{c}0.725 \\
(0.183)\end{array}$ & 0.006 \\
\hline Family size & $\begin{array}{c}3.184 \\
(0.194)\end{array}$ & $\begin{array}{c}3.143 \\
(0.151)\end{array}$ & $\begin{array}{c}3.213 \\
(0.214)\end{array}$ & 0.071 \\
\hline Percent of adults with BA & $\begin{array}{l}22.09 \\
(4.755)\end{array}$ & $\begin{array}{l}22.92 \\
(5.483)\end{array}$ & $\begin{array}{l}21.50 \\
(4.055)\end{array}$ & -1.42 \\
\hline Percent of adults with HS & $\begin{array}{l}79.30 \\
(6.127)\end{array}$ & $\begin{array}{l}79.12 \\
(6.470)\end{array}$ & $\begin{array}{l}79.44 \\
(5.866)\end{array}$ & 0.31 \\
\hline Veh. miles trav. per capita $(000 \mathrm{~s})$ & $\begin{array}{l}13.2 \\
(2.33)\end{array}$ & $\begin{array}{l}12.9 \\
(2.22)\end{array}$ & $\begin{array}{l}13.4 \\
(2.38)\end{array}$ & 0.5 \\
\hline Percent state budget surplus & $\begin{array}{c}0.0953 \\
(0.109)\end{array}$ & $\begin{array}{l}0.09 \\
(0.105)\end{array}$ & $\begin{array}{l}0.10 \\
(0.112)\end{array}$ & 0.01 \\
\hline Senator LCV score & $\begin{array}{c}46.96 \\
(31.03)\end{array}$ & $\begin{array}{c}51.87 \\
(33.23)\end{array}$ & $\begin{array}{c}43.45 \\
(28.86)\end{array}$ & -8.41 \\
\hline House LCV score & $\begin{array}{c}44.58 \\
(24.61)\end{array}$ & $\begin{array}{c}53.15 \\
(26.38)\end{array}$ & $\begin{array}{c}38.47 \\
(21.25)\end{array}$ & $-14.68 * *$ \\
\hline Democrat governor & $\begin{array}{c}0.457 \\
(0.497)\end{array}$ & $\begin{array}{c}0.484 \\
(0.499)\end{array}$ & $\begin{array}{c}0.437 \\
(0.495)\end{array}$ & -0.046 \\
\hline Democrat fraction of state senate & $\begin{array}{c}0.546 \\
(0.168)\end{array}$ & $\begin{array}{c}0.576 \\
(0.183)\end{array}$ & $\begin{array}{c}0.522 \\
(0.152)\end{array}$ & -0.054 \\
\hline Democrat fraction of state house & $\begin{array}{c}0.546 \\
(0.162)\end{array}$ & $\begin{array}{c}0.568 \\
(0.192)\end{array}$ & $\begin{array}{c}0.528 \\
(0.132)\end{array}$ & -0.040 \\
\hline
\end{tabular}

Notes: The first, second, and third columns report the mean and standard deviation of each variable for the full sample, the subset of states not changing the point of collection, and the subset of states that changed the point of collection at some point during the period. The unit of observation is the state-month level. The fourth column is the difference between columns two and three, where significance is based on standard errors clustered by state.

*** Significant at the 1 percent level.

** Significant at the 5 percent level.

* Significant at the 10 percent level. 
Table 4-Predictors of Tax Changes and Changes in Point of TaXation

\begin{tabular}{|c|c|c|c|c|}
\hline & $\begin{array}{l}\Delta \text { Retailer } \\
\text { remittance } \\
(1)\end{array}$ & $\begin{array}{c}\Delta \text { Distributor } \\
\text { remittance } \\
(2)\end{array}$ & $\begin{array}{c}\Delta \text { Supplier } \\
\text { remittance } \\
(3)\end{array}$ & $\begin{array}{c}\Delta \text { State } \\
\text { diesel tax } \\
(4)\end{array}$ \\
\hline Tax-excl. diesel price & $\begin{array}{c}-0.00324 \\
(0.00222)\end{array}$ & $\begin{array}{c}-0.000699 \\
(0.00212)\end{array}$ & $\begin{array}{c}0.00394 \\
(0.00288)\end{array}$ & $\begin{array}{c}-0.00535 \\
(0.0152)\end{array}$ \\
\hline GSP per capita & $\begin{array}{c}-0.00712 \\
(0.00463)\end{array}$ & $\begin{array}{r}-0.00214 \\
(0.00819)\end{array}$ & $\begin{array}{c}0.00925 \\
(0.00797)\end{array}$ & $\begin{array}{c}-0.155^{* *} \\
(0.0622)\end{array}$ \\
\hline Unemployment rate & $\begin{array}{c}-0.0105 \\
(0.00885)\end{array}$ & $\begin{array}{c}0.0163 \\
(0.0135)\end{array}$ & $\begin{array}{c}-0.00585 \\
(0.00913)\end{array}$ & $\begin{array}{c}0.0989 \\
(0.0699)\end{array}$ \\
\hline GSP share—manufacturing & $\begin{array}{r}-0.380 \\
(0.478)\end{array}$ & $\begin{array}{l}0.00943 \\
(0.666)\end{array}$ & $\begin{array}{c}0.370 \\
(0.557)\end{array}$ & $\begin{array}{c}5.948 \\
(3.654)\end{array}$ \\
\hline GSP share-mining & $\begin{array}{c}0.322 \\
(0.291)\end{array}$ & $\begin{array}{c}-1.143 * * \\
(0.510)\end{array}$ & $\begin{array}{c}0.821 \\
(0.575)\end{array}$ & $\begin{array}{c}8.908 \\
(6.793)\end{array}$ \\
\hline GSP share-farming & $\begin{array}{r}-0.730 \\
(0.809)\end{array}$ & $\begin{array}{r}-1.386 \\
(1.056)\end{array}$ & $\begin{array}{c}2.116 \\
(1.746)\end{array}$ & $\begin{array}{c}2.318 \\
(7.502)\end{array}$ \\
\hline GSP share-petroleum & $\begin{array}{c}0.825 \\
(0.920)\end{array}$ & $\begin{array}{c}0.713 \\
(1.344)\end{array}$ & $\begin{array}{r}-1.538 \\
(0.999)\end{array}$ & $\begin{array}{c}-20.27 * * * \\
(6.320)\end{array}$ \\
\hline GSP share_trucking & $\begin{array}{c}-5.074 \\
(9.352)\end{array}$ & $\begin{array}{l}-6.861 \\
(11.82)\end{array}$ & $\begin{array}{l}11.93 \\
(9.216)\end{array}$ & $\begin{array}{c}-63.21 \\
(117.6)\end{array}$ \\
\hline Population & $\begin{array}{c}-0.00898 \\
(0.0784)\end{array}$ & $\begin{array}{r}-0.137 * \\
(0.0753)\end{array}$ & $\begin{array}{c}0.146^{*} \\
(0.0802)\end{array}$ & $\begin{array}{r}-0.561 \\
(0.575)\end{array}$ \\
\hline Urban pop. share & $\begin{array}{c}-2.409 \\
(2.091)\end{array}$ & $\begin{array}{c}5.638 \\
(3.443)\end{array}$ & $\begin{array}{r}-3.229 \\
(3.913)\end{array}$ & $\begin{array}{r}-18.85 \\
(24.34)\end{array}$ \\
\hline Fraction of adults with BA & $\begin{array}{c}0.0249 \\
(0.0279)\end{array}$ & $\begin{array}{c}0.0566 \\
(0.0468)\end{array}$ & $\begin{array}{c}-0.0815^{* * *} \\
(0.0379)\end{array}$ & $\begin{array}{r}-0.281 \\
(0.500)\end{array}$ \\
\hline Fraction of adults grad. HS & $\begin{array}{c}0.0271 * \\
(0.0146)\end{array}$ & $\begin{array}{c}-0.0580^{* * *} \\
(0.0218)\end{array}$ & $\begin{array}{l}0.0308 * * \\
(0.0139)\end{array}$ & $\begin{array}{c}-0.399 * \\
(0.220)\end{array}$ \\
\hline Vehicle miles trav. per capita & $\begin{array}{c}0.00246 \\
(0.00571)\end{array}$ & $\begin{array}{c}0.00293 \\
(0.00628)\end{array}$ & $\begin{array}{c}-0.00539 \\
(0.00712)\end{array}$ & $\begin{array}{c}0.455 \\
(0.348)\end{array}$ \\
\hline Percent state budget surplus & $\begin{array}{c}0.0161 \\
(0.0252)\end{array}$ & $\begin{array}{c}0.0413 \\
(0.0447)\end{array}$ & $\begin{array}{r}-0.0573 \\
(0.0518)\end{array}$ & $\begin{array}{r}-0.223 \\
(0.456)\end{array}$ \\
\hline Senator LCV score & $\begin{array}{c}-0.0000519 \\
(0.000131)\end{array}$ & $\begin{array}{c}-0.0000770 \\
(0.000397)\end{array}$ & $\begin{array}{c}0.000129 \\
(0.000422)\end{array}$ & $\begin{array}{r}-0.00265 \\
(0.00289)\end{array}$ \\
\hline House LCV score & $\begin{array}{r}-0.000209 \\
(0.000207)\end{array}$ & $\begin{array}{c}0.000259 \\
(0.000347)\end{array}$ & $\begin{array}{r}-0.0000499 \\
(0.000335)\end{array}$ & $\begin{array}{c}0.00151 \\
(0.00304)\end{array}$ \\
\hline Democrat governor & $\begin{array}{c}-0.00863 \\
(0.0110)\end{array}$ & $\begin{array}{r}-0.00194 \\
(0.00517)\end{array}$ & $\begin{array}{c}0.0106 \\
(0.00948)\end{array}$ & $\begin{array}{c}0.0973 \\
(0.218)\end{array}$ \\
\hline Dem. fraction of state senate & $\begin{array}{c}-0.0882 \\
(0.0929)\end{array}$ & $\begin{array}{c}0.107 \\
(0.0922)\end{array}$ & $\begin{array}{r}-0.0190 \\
(0.0649)\end{array}$ & $\begin{array}{c}-0.192 \\
(0.620)\end{array}$ \\
\hline Dem. fraction of state house & $\begin{array}{c}-0.0855 \\
(0.0783)\end{array}$ & $\begin{array}{c}-0.00869 \\
(0.145)\end{array}$ & $\begin{array}{c}0.0942 \\
(0.138)\end{array}$ & $\begin{array}{c}-0.460 \\
(1.237)\end{array}$ \\
\hline $\begin{array}{l}\text { Observations } \\
R^{2}\end{array}$ & $\begin{array}{r}819 \\
0.0749\end{array}$ & $\begin{array}{r}819 \\
0.0516\end{array}$ & $\begin{array}{r}819 \\
0.0807\end{array}$ & $\begin{array}{c}819 \\
0.115\end{array}$ \\
\hline
\end{tabular}

Notes: The dependent variable of each regression is listed in the panel header rows. The unit of observation is the state-month level. Standard errors clustered by year are in parentheses. All dependent and independent variables are first-differenced. All specifications include year fixed effects.

*** Significant at the 1 percent level.

** Significant at the 5 percent level.

* Significant at the 10 percent level.

between changes in state diesel taxes and the covariates. Increases in the state diesel tax rate are less likely in quickly growing states and states for which a rising share of gross state product comes from the petroleum industry. 


\section{B. Methodology}

Point of Taxation and Incidence.-We examine the degree to which diesel taxes are passed through to retail prices using variation across states and over time in state diesel tax rates and the point of tax collection. Ideally, we would observe the price charged by bulk terminals to wholesale distributors, and by wholesale distributors to retail stations; this would allow for a direct evaluation of the burden of taxation across different levels of the supply chain. Unfortunately, data limitations preclude this level of analysis, and so we must rely on an analysis of retail prices, which we argued (in the theory section) reflects changes in incidence higher up the supply chain. For instance, if changing the point of tax collection raises the price that wholesalers charge retailers, then this higher cost for retailers will be reflected in the price they charge to consumers.

To be specific, we estimate a specification of monthly real tax-exclusive retail diesel prices, deflated using the consumer price index: ${ }^{14}$

$$
p_{i t}=\beta_{0}+\beta_{1} \tau_{i t}+\beta_{2} \text { regime }_{i t}+\beta_{3} \tau_{i t} \times \text { regime }_{i t}+\mathbf{B X} \mathbf{X}_{i t}+\epsilon_{i t},
$$

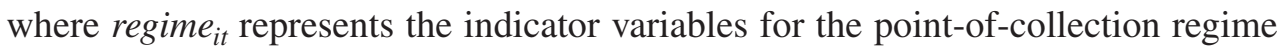
employed by state $i$ in month $t, \tau_{i t}$ is the diesel tax rate and $\mathbf{X}_{i t}$ is a vector of covariates including state economic conditions, state, and year $\times$ month effects, the minimum of the diesel tax rates in neighboring states, and the portion of households who use fuel oil for home heating, interacted with heating degree days. Under the null hypothesis of collection-point irrelevance, both $\beta_{2}$ and $\beta_{3}$ are zero.

One extension to the primary specification given by (1) that we pursue is to allow for the key coefficients in the model to vary over time. It is possible that the elasticity of demand for diesel fuel changes over time in an unobservable way, which could alter the predicted degree of pass-through. Because the point of collection has on average moved up the supply chain over time, this could lead us to mistakenly attribute changes in incidence to the point of taxation that are actually due to shifts in demand elasticity. Similarly, changes in regulations or refinery capacity over time could alter the supply elasticity in a manner correlated with trends in the point of taxation. To correct for this, we will also estimate a version of (1) that allows for a time varying value of $\beta_{1}$ by controlling for a full set of year-tax interactions.

Remittance, Evasion, and Tax Collections.-We next use the data on taxed quantities from the FHWA to evaluate the impact of point of tax collection on the extent of tax evasion. We do not observe tax evasion directly. However, if changing the point of tax collection affects evasion, then ceteris paribus tax collections should change as more or less taxable gallons are reported. This focus on traces of evasion is a standard strategy in the empirical study of tax evasion, as discussed in Slemrod and Weber (2012).

\footnotetext{
${ }^{14}$ The dependent variable is the retail price charged at the pump, exclusive of taxes owed. Therefore, if the price at the pump is $\$ 4$ per gallon, the federal tax is 24.4 cents per gallon, and the state tax is 25 cents per gallon, the dependent variable would take on a value of $\$ 3.506$.
} 
We examine the correlation between the tax collection regime and taxed gallons. In particular, we estimate an equation of the form

$$
\begin{aligned}
\ln \left(q_{i t}\right)= & \alpha_{0}+\alpha_{1} \ln \left(p_{i t}\right)+\alpha_{2} \ln \left(1+\tau_{i t} / p_{i t}\right) \\
& +\alpha_{3} \text { regime }_{i t}+\mathbf{A} \Delta \mathbf{X}_{i t}+\gamma_{i}+\rho_{t}+\epsilon_{i t},
\end{aligned}
$$

where regime $_{i t}$ again represents the point-of-collection regime employed by state $i$. We model the log of taxed gallons as a function of the log of the tax inclusive price, $\ln (p+t)$. To separately identify the response of taxed gallons to the tax rate from the response to the price, we factor out the price from this expression. As stressed by Slemrod (2001), the parameter $\alpha_{2}$ need not equal $\alpha_{1}$ because the response to the tax rate need not be the same as the response to the pre-tax price in the presence of avoidance and evasion. Kopczuk (2005) and Slemrod and Kopczuk (2002) point out that the size of the tax base as well as the degree of enforcement can both influence the elasticity of tax collections to the tax rate. As in the price specification, the vector of covariates in $\mathbf{X}_{i t}$ includes state economic conditions, the minimum of the tax rate in neighboring states, and the weather and its interaction with household use of fuel oil for home heating. The variable $\rho_{t}$ represents common year effects, while $\gamma_{i}$ represents state effects. Under the null hypothesis of collection-point irrelevance, $\alpha_{3}$ is zero.

To examine preexisting differences between the different tax regimes, and to verify that any changes in tax collections correspond to the regime change, we will also examine graphically the coefficients $\beta_{t-j}^{k}$ from the following regression:

$$
\ln \left(q_{i t}\right)=\beta_{0}+\sum_{k} \sum_{j=-2}^{2} \beta_{t-j}^{k} I\left(d_{i, t-j}^{k}\right)+\phi_{t}+\rho_{i}+\epsilon_{i t},
$$

where $k$ indexes the three types of transitions witnessed in the data: retailer-todistributor collection, retailer-to-supplier, and distributor-to-supplier. $I\left(d_{i, t-j}^{k}\right)$ is an indicator for whether the type of transition $k$ occurred in year $t-j$. This exercise will yield the average residual tax collections in the periods before and after each type of regime transition that we observe in the data.

\section{Results}

\section{A. Tax Incidence Results}

In this section, we present estimates of the effect of the point of tax collection on retail diesel prices. In Table 5, we show the results of estimating equation (1), where the dependent variable is the real retail price, excluding federal and state taxes. In column 1 of this table, we show the results of including only the diesel tax rate and control variables, and excluding any information about the party responsible for tax collection. The coefficient on the diesel tax variable suggests that the net-of-tax retail price falls 0.86 cents for every 10 -cent increase in the diesel tax. The interpretation of this coefficient is that nearly all ( 91.4 percent) of the tax burden is born by consumers, and the amount suppliers received per gallon from consumers falls 
Table 5-Point of Tax Collection and Incidence

\begin{tabular}{|c|c|c|c|c|}
\hline & (1) & (2) & (3) & (4) \\
\hline Real diesel tax & $\begin{array}{c}-0.086^{* * *} \\
(0.021)\end{array}$ & $\begin{array}{r}-0.025 \\
(0.022)\end{array}$ & $\begin{array}{c}-0.120^{* *} * \\
(0.055)\end{array}$ & \\
\hline Collect tax from supplier & & $\begin{array}{l}2.875^{* * * *} \\
(0.268)\end{array}$ & $\begin{array}{c}0.445 \\
(0.604)\end{array}$ & $\begin{array}{c}0.824 \\
(0.658)\end{array}$ \\
\hline Collect tax from distributor & & $\begin{array}{l}1.378 * * * \\
(0.188)\end{array}$ & $\begin{array}{c}0.192 \\
(0.626)\end{array}$ & $\begin{array}{c}-0.308 \\
(0.656)\end{array}$ \\
\hline Real tax $\times$ collect from supplier & & & $\begin{array}{l}0.209 * * * \\
(0.052)\end{array}$ & $\begin{array}{l}0.162 * * * \\
(0.057)\end{array}$ \\
\hline Real tax $\times$ collect from distributor & & & $\begin{array}{c}0.100^{*} \\
(0.056)\end{array}$ & $\begin{array}{l}0.139 * * \\
(0.057)\end{array}$ \\
\hline Real minimum neighbor's tax & $\begin{array}{c}0.080 * \\
(0.046)\end{array}$ & $\begin{array}{l}0.275^{* * *} \\
(0.051)\end{array}$ & $\begin{array}{l}0.276^{* * * *} \\
(0.050)\end{array}$ & $\begin{array}{l}0.249 * * * \\
(0.051)\end{array}$ \\
\hline Degree days & $\begin{array}{c}0.087 \\
(0.066)\end{array}$ & $\begin{array}{c}0.094 \\
(0.063)\end{array}$ & $\begin{array}{c}0.095 \\
(0.062)\end{array}$ & $\begin{array}{c}0.078 \\
(0.061)\end{array}$ \\
\hline Degree days $\times \mathrm{HH}$ fuel oil frac & $\begin{array}{l}0.468 * * * \\
(0.085)\end{array}$ & $\begin{array}{l}0.460 * * * \\
(0.080)\end{array}$ & $\begin{array}{l}0.460 * * * \\
(0.079)\end{array}$ & $\begin{array}{l}0.459 * * * \\
(0.078)\end{array}$ \\
\hline Unemp. rate & $\begin{array}{c}-0.064 \\
(0.061)\end{array}$ & $\begin{array}{c}-0.128 * * \\
(0.062)\end{array}$ & $\begin{array}{c}-0.135^{* *} \\
(0.063)\end{array}$ & $\begin{array}{c}-0.132 * * \\
(0.062)\end{array}$ \\
\hline Real diesel tax $\times$ year dummies & & & & $\mathrm{X}$ \\
\hline $\begin{array}{l}\text { Observations } \\
R^{2}\end{array}$ & $\begin{array}{l}5,435 \\
0.98\end{array}$ & $\begin{array}{l}5,435 \\
0.98\end{array}$ & $\begin{array}{l}5,435 \\
0.98\end{array}$ & $\begin{array}{l}5,435 \\
0.98\end{array}$ \\
\hline
\end{tabular}

Notes: The dependent variable is the real tax-exclusive retail price of No. 2 diesel. Each specification includes state fixed effects and year $\times$ month effects. Standard errors clustered by year $\times$ month are in parentheses.

*** Significant at the 1 percent level.

** Significant at the 5 percent level.

* Significant at the 10 percent level.

little as taxes rise. Other estimated coefficients are similar to those found in Marion and Muehlegger (2011). Prices rise as the minimum tax rate in neighboring states increases, and prices are higher in cold months where households tend to use diesel for home heating. ${ }^{15}$ Lastly, economic activity is correlated with prices, as the unemployment rate has a negative association with prices, likely due to reduced demand.

The specification shown in column 2 includes indicators for whether the state collects at the distributor level or at the bulk terminal. The excluded category are states collecting the diesel tax from retail outlets. Compared to states collecting at the retail level, states in which the party responsible for remitting the tax is the prime supplier have a retail price that is 2.88 cents higher, and those taxing the wholesale distributor have a retail price that is 1.38 cents higher. Both of these coefficients are consistent with the hypothesis that retail stations are relatively more difficult for tax authorities to monitor and that the relatively small number of bulk terminals makes evasion more costly for these firms, and are inconsistent with the null hypothesis of collection-point irrelevance.

\footnotetext{
${ }^{15}$ The estimated coefficient on other states' taxes depends somewhat on how those states are weighted. Here we place a weight of one on the minimum of the neighboring state, although using the average tax in neighboring states leads to a coefficient closer to zero.
} 
In column 3 of Table 5, we show the results of estimating a specification including interactions between the remittance regime dummy variables and the tax rate, which allows the pass-through rate of diesel taxes to prices to depend on the point of collection. The estimated coefficients on the interaction between diesel taxes and the collect from the distributor and terminal indicators are 0.10 and 0.21 , respectively; both are statistically different from zero, although the former is only marginally so $(p$-value $=0.073)$. This suggests that the pass-through rate rises as the tax collection point is moved up the supply chain. Furthermore, the pass-through rate is highest when collecting from the bulk terminal, as the coefficient on the interaction between the tax rate and the supplier collection dummy is higher than the coefficient on the similar interaction with the distributor collection dummy ( $p$-value $=0.081$ ). This result is also consistent with the observation that the prime supplier is the easiest point in the supply chain for tax authorities to monitor.

It is worth noting that the sum of the main effect and the interaction effect in the case of taxing at the bulk terminal leads to an estimated pass-through rate of greater than 100 percent. The estimates suggest that the tax-inclusive retail price rises by 1.089 cents for each 1-cent increase in the diesel tax. However, this is not statistically distinguishable from full pass-through $(p=0.14)$, which is a reasonable baseline, as it is the upper bound of the pass-through rate in a competitive model without differential evasion opportunities.

Finally, the specification displayed in column 4 includes a full set of year-bydiesel tax rate interactions, which allows the rate of tax pass-through to vary over time. This is of interest due to the time trend in the point of taxation and because factors that may influence the elasticity of supply and demand, such as environmental regulations and the demand for untaxed uses of diesel, may have shifted over time. Hence, if general pass-through rate has been trending, we may be mistakenly ascribing it to shifts in point of taxation. It turns out, however, that allowing for time-varying pass-through rates has little effect on the estimated parameters of interest. The direct effect of the point of tax collection is small and indistinguishable from zero, and the estimated interaction terms between the diesel tax and the indicators for the collection point being the terminal and the distributor are 0.16 and 0.14 , respectively, very little changed from the primary specification.

Accounting for Trends in Pass-Through.-The above approach compares the pass-through rate in a state after a change in the point of collection with the pass-through rate prior to the shift. Therefore, unobserved characteristics affecting pass-through in a state that are fixed over time will not affect our results. However, our estimates will be biased if unobserved variables that alter rates of tax passthrough are moving over time in a way that is correlated with the change in tax collection regime. For instance, if the number of bulk terminals changes over time in a state, the tax authorities may find it more desirable to collect the tax from the prime supplier owing to the number of taxable agents. Such a change may also alter the rate of tax pass-through by changing the elasticity of supply with respect to price. ${ }^{16}$

\footnotetext{
${ }^{16}$ Another potential omitted variable is the extent of market power in this industry. We investigate controlling for wholesale market concentration in the Appendix of Kopczuk et al. (2016), and find that it does not affect our
} 
TABle 6-Point of Tax Collection and InCidence

\begin{tabular}{|c|c|c|c|c|}
\hline & \multicolumn{4}{|c|}{ States shifting point of taxation from: } \\
\hline & \multicolumn{2}{|c|}{ Distributor to supplier } & \multicolumn{2}{|c|}{ Retailer to distributor } \\
\hline & (1) & (2) & (3) & (4) \\
\hline Real diesel tax & $\begin{array}{c}-0.149 \\
(0.100)\end{array}$ & $\begin{array}{r}-0.150 \\
(0.140)\end{array}$ & $\begin{array}{c}-0.319^{* * *} \\
(0.089)\end{array}$ & $\begin{array}{c}-0.315^{* * *} \\
(0.085)\end{array}$ \\
\hline Real tax $\times$ post reform & $\begin{array}{l}0.227 * * \\
(0.090)\end{array}$ & $\begin{array}{c}0.229 \\
(0.151)\end{array}$ & $\begin{array}{l}0.677 * * * \\
(0.087)\end{array}$ & $\begin{array}{l}0.677 * * * \\
(0.088)\end{array}$ \\
\hline Post reform & $\begin{array}{r}-1.555 \\
(0.986)\end{array}$ & $\begin{array}{r}-1.583 \\
(1.765)\end{array}$ & $\begin{array}{c}-5.363^{* * *} * \\
(0.943)\end{array}$ & $\begin{array}{l}-5.400 * * * \\
(1.003)\end{array}$ \\
\hline Real tax $\times$ months relative to change & & $\begin{array}{c}-0.00002 \\
(0.001)\end{array}$ & & $\begin{array}{c}0.0001 \\
(0.001)\end{array}$ \\
\hline Months relative to regime change & & $\begin{array}{l}0.070 \text { *** } \\
(0.010)\end{array}$ & & $\begin{array}{l}0.161 * * * \\
(0.012)\end{array}$ \\
\hline Observations & 1,004 & 1,004 & 751 & 751 \\
\hline$R^{2}$ & 0.98 & 0.98 & 0.99 & 0.99 \\
\hline
\end{tabular}

Notes: The dependent variable is the real tax-exclusive retail price of No. 2 diesel. Standard errors are in parentheses. The other covariates are identical to those included in the specification shown in column 3 of Table 4 . Months relative to regime change is a variable equal to the number of months prior to or after the stated regime change. Specifications (1) and (2) include all observations from states that experienced a shift in the point of collection from the wholesale distributor level to the prime supplier level. Specifications (3) and (4) likewise include all observations from states that experienced a shift in the point of collection from the retail level to the wholesale distributor level.

*** Significant at the 1 percent level.

** Significant at the 5 percent level.

* Significant at the 10 percent level.

To address this concern, we further exploit the timing of the change in the remitting party by accounting for trends in pass-through relative to the date of the regime change, examining whether pass-through changed discontinuously at the date of the regime change. This is conceptually similar to a parametric regression discontinuity design, where the running variable is time, and the threshold is the date of the policy change.

We consider states that undertook a particular regime change, either shifting from retailer to distributor collection or from distributor to prime supplier. ${ }^{17}$ We center the data such that the date of the state $i$ 's regime shift is $t_{i}^{0}$. We then estimate our standard pass-through specification, adding an interaction term $\tau_{i t} \times\left(t-t_{i}^{0}\right)$ as well as the direct effect $t-t_{i}^{0}$. This allows the estimated pass-through rate to differ in a linear fashion over time, and we can therefore examine the post-regime difference in pass-through relative to this trend.

We present the results in Table 6. Columns 1 and 2 contain the results from estimating the pass-through equation for states moving the point of collection from the wholesale distributor to the prime supplier. Pass-through is greater after the move to the supplier level, as seen in column 1. Furthermore, the results in column 2 indicate that there is no trend in pass-through relative to the date of the regime change, nor

results. Alternatively, this exercise may be interpreted as testing the heterogeneity of the pass-through effects with respect to the market power; we find no evidence of it.

${ }^{17}$ The other upstream transitions witnessed in the data are retailer-to-supplier, of which there have been five during our sample. We are unable to specifically use these in this exercise because we observe price for only two of these transitions. 
Table 7-Point of Tax Collection and Wholesale Prices

\begin{tabular}{|c|c|c|c|c|}
\hline & \multicolumn{4}{|c|}{ Dependent variable: } \\
\hline & \multicolumn{2}{|c|}{ Resale price } & \multicolumn{2}{|c|}{ Retail price } \\
\hline & (1) & (2) & (3) & (4) \\
\hline Real diesel tax & $\begin{array}{c}-0.002 \\
(0.017)\end{array}$ & $\begin{array}{r}-0.024 \\
(0.039)\end{array}$ & $\begin{array}{c}-0.120^{* *} \\
(0.055)\end{array}$ & $\begin{array}{c}-0.098 * \\
(0.051)\end{array}$ \\
\hline Collect tax from supplier & $\begin{array}{l}1.959 * * * \\
(0.260)\end{array}$ & $\begin{array}{c}-0.803^{* *} \\
(0.405)\end{array}$ & $\begin{array}{c}0.445 \\
(0.605)\end{array}$ & $\begin{array}{c}0.987 * \\
(0.564)\end{array}$ \\
\hline Collect tax from distributor & $\begin{array}{l}0.686^{* * * *} \\
(0.164)\end{array}$ & $\begin{array}{c}0.575 \\
(0.409)\end{array}$ & $\begin{array}{c}0.192 \\
(0.627)\end{array}$ & $\begin{array}{r}-0.296 \\
(0.615)\end{array}$ \\
\hline Real tax $\times$ collect from supplier & & $\begin{array}{l}0.240^{* * *} \\
(0.037)\end{array}$ & $\begin{array}{l}0.209 * * * \\
(0.053)\end{array}$ & $\begin{array}{c}0.028 \\
(0.044)\end{array}$ \\
\hline Real tax $\times$ collect from distributor & & $\begin{array}{c}0.001 \\
(0.039)\end{array}$ & $\begin{array}{c}0.100 * \\
(0.056)\end{array}$ & $\begin{array}{l}0.099 * * \\
(0.050)\end{array}$ \\
\hline Real price for resale & & & & $\begin{array}{l}0.535 * * * \\
(0.036)\end{array}$ \\
\hline Lag real price for resale & & & & $\begin{array}{l}0.240 * * * \\
(0.038)\end{array}$ \\
\hline Observations & 5,427 & 5,427 & 5,435 & 5,349 \\
\hline$R^{2}$ & 0.99 & 0.99 & 0.98 & 0.99 \\
\hline
\end{tabular}

Notes: The dependent variable in columns 1 and 2 is the average price charged for diesel that will be resold to another party. The dependent variable in columns 3 and 4 is the real tax-exclusive retail price of No. 2 diesel. Standard errors clustered by year-month are in parentheses. The other included controls correspond to those in the specification shown in column 4 of Table 5 .

**** Significant at the 1 percent level.

** Significant at the 5 percent level.

* Significant at the 10 percent level.

does including this interaction term alter the estimated coefficient on the variable of interest. A similar story emerges when we examine retailer-to-distributor regime changes, as shown in columns 3 and 4. The pass-through rate is higher when the state requires the tax to be remitted by the distributor compared to when it requires the tax to be remitted by the retailer. Furthermore, this set of states does not experience a trend in incidence relative to the date of the regime change, nor does allowing for such a trend alter the primary coefficient of interest.

Price for Resale.-Our results suggest that collecting the tax from the prime supplier raises the portion of the tax that is passed through to the retail price. Because the prime supplier first sells diesel through a wholesale intermediary, this passthrough must first show up in the price for resale. Furthermore, when taxing the prime supplier, the retail price effect of the tax must occur entirely via the resale price. In this section, we describe estimates of the effect of the point of collection on the wholesale price of diesel, and we examine how taxes work through to retail prices via the wholesale price when the tax is collected from the prime supplier.

In column 1 of Table 7, we present estimates of our baseline incidence specification, now with the real resale price as the dependent variable. We see that the price for resale is around 2 cents higher when the tax is collected from the prime supplier, and 0.7 cents higher when collected from the distributor level, compared to when 
the tax is collected at the retail level. On average, the tax has virtually no effect on the net-of-tax resale price. In the specification shown in column 2 , we include the interaction between the tax and indicators for collecting from the distributor and the prime supplier. When the tax is collected from the prime supplier, an increase in the tax leads to an increase in the wholesale resale price. A 10-cent per gallon tax increase leads to a 2.4-cent increase in the resale price in supplier-remitting states relative to retailer-remitting states. Conversely, tax changes have virtually no effect on the resale price in distributor-remitting states or retailer-remitting states. This will be true if sales by prime suppliers make up the bulk of the sales used to calculate the price of diesel for resale.

We are able to show what implications this has for retail price incidence. In column 3 of Table 7, we restate the results of column 3 of Table 5, which shows that a 10 -cent tax rate increases the retail price by 2.1 cents in a supplier-remitting state relative to a similar tax change in a retailer-remitting state. In column 4 , we show the results of estimating a similar specification, where we also include as control variables the concurrent and lagged price of diesel for resale. Controlling for resale price, the estimated coefficient on the tax $\times$ supplier remitter interaction is now 0.028 , substantially smaller than the base specification estimate of 0.21 . The differential effect of tax on retail prices in supplier-remitting states is thus almost entirely explained by the effect on the wholesale price, just as one would expect if our results are valid.

\section{B. Market Power and Pass-Through}

A more specific concern about unobserved heterogeneity relates to the correlation between market power and tax pass-through, illustrated by Weyl and Fabinger (2013). In the Appendix in Kopczuk et al. (2016) we illustrate theoretically that, conditional on concentration, moving the point of taxation from a part of the supply chain with high concentration to one of low concentration does not affect pass-through. If the tax regime is correlated with the concentration of firms in the supply chain, though, we may misattribute an effect of concentration to our tax regime variables.

As a direct test of this concern, we add covariates reflecting market concentration to our main specification and demonstrate that the inclusion of the covariates does not account for the differences in observed pass-through rates by regime. As our measure of market concentration, we calculate Hirschman-Herfindahl indices (HHI) for each state using restricted, firm-level microdata collected by the Energy Information Administration. ${ }^{18}$ For each state and month, we calculate state-level HHIs based on the wholesale volumes sold by each firm. For reference, the mean $\mathrm{HHI}$ in our sample is 0.22 - the top four firms in each market account for 74 percent of wholesale volumes, on average.

The one limitation is that firm-level microdata is only available from 1994-2006. By 1994, half of the states that collected taxes from retailers in 1986 have already

\footnotetext{
${ }^{18}$ We focus on wholesale concentration rather than retail market concentration for two reasons. First, most retail stations are franchisee-owned and determining historical ownership and operational control is difficult. Second, retail stations tend to compete very locally as discussed in Hastings (2004) and Houde (2012). State-level statistics are an imperfect proxy for retail competition.
} 
Table 8-Pass-Through and Wholesale Concentration

\begin{tabular}{|c|c|c|c|c|}
\hline & \multirow{2}{*}{$\frac{\text { Full sample }}{(1)}$} & \multicolumn{3}{|c|}{ 1994-2006 subsample } \\
\hline & & (2) & (3) & (4) \\
\hline Diesel tax & $\begin{array}{c}-0.120^{* * *} \\
(0.055)\end{array}$ & $\begin{array}{c}-0.353 \\
(0.216)\end{array}$ & $\begin{array}{c}-0.445^{*} \\
(0.242)\end{array}$ & $\begin{array}{c}-0.406 \\
(0.251)\end{array}$ \\
\hline Supp remit $\times$ diesel tax & $\begin{array}{l}0.209 * * * \\
(0.052)\end{array}$ & $\begin{array}{l}0.638 * * * \\
(0.177)\end{array}$ & $\begin{array}{l}0.712 * * * \\
(0.199)\end{array}$ & $\begin{array}{l}0.524 * * \\
(0.213)\end{array}$ \\
\hline Dist remit $\times$ diesel tax & $\begin{array}{c}0.100 * \\
(0.056)\end{array}$ & $\begin{array}{c}0.308 \\
(0.210)\end{array}$ & $\begin{array}{c}0.375 \\
(0.229)\end{array}$ & $\begin{array}{c}0.340 \\
(0.244)\end{array}$ \\
\hline Demeaned HHI & & & $\begin{array}{c}-3.968 \\
(2.716)\end{array}$ & $\begin{array}{c}25.12 \\
(23.26)\end{array}$ \\
\hline Supp remit $\times \mathrm{HHI}$ & & & & $\begin{array}{c}21.35 \\
(26.54)\end{array}$ \\
\hline Dist remit $\times \mathrm{HHI}$ & & & & $\begin{array}{c}-29.46 \\
(23.42)\end{array}$ \\
\hline Diesel tax $\times$ HHI & & & $\begin{array}{c}0.330 \\
(0.208)\end{array}$ & $\begin{array}{c}-3.429 \\
(2.809)\end{array}$ \\
\hline Supp remit $\times$ diesel tax $\times$ HHI & & & & $\begin{array}{c}-0.930 \\
(3.064)\end{array}$ \\
\hline Dist remit $\times$ diesel tax $\times$ HHI & & & & $\begin{array}{c}3.805 \\
(2.819)\end{array}$ \\
\hline Observations & 5,435 & 3,350 & 3,346 & 3,346 \\
\hline$R^{2}$ & 0.982 & 0.990 & 0.990 & 0.990 \\
\hline
\end{tabular}

Notes: The dependent variable is the real tax-exclusive retail price of No. 2 diesel. Standard errors clustered by year $\times$ month are in parentheses. For reference, the mean and standard deviation of HHI are 0.22 and 0.16 . All specifications include regime dummies, identical covariates to column 3 of Table 5 , state fixed effects, and year $\times$ month effects.

*** Significant at the 1 percent level.

** Significant at the 5 percent level.

* Significant at the 10 percent level.

shifted the point of collection upstream. Six of the remaining eight states that collect taxes from retailers shifted the point of collection upstream by 1999. This limits our sample of tax changes in retailer-remitting states and consequently reduces the precision with which we can estimate pass-through in these states.

Table 8 introduces market concentration into our main specification. For reference, column 1 replicates the results from the main specification (column 3 ) from Table 5 and column 2 presents an identical specification limited to the time period for which we have access to the firm-level microdata. Comparing columns 1 and 2, we see that our estimates are less precise when we limit the sample to the period 1994-2006. This is most apparent in the estimate of pass-through in the retail-remitting states (the coefficient on Diesel Tax, as retailer-remitting states are the omitted category from the regime-tax interaction terms). Despite lower precision, we continue to find evidence that the pass-through is higher in supplier-remitting states than retailer-remitting states. In addition, our point estimates of pass-through in supplier-remitting states and distributor-remitting states are similar before and after limiting the sample. ${ }^{19}$

\footnotetext{
${ }^{19}$ The sum of the main effect and the supplier-remitting state $\times$ tax interaction is 0.089 in the full sample and 0.275 in the subsample. For distributor-remitting states, the sum of the main effect and interaction term is -0.02 in the full sample and -0.045 in the subsample.
} 
In columns 3 and 4, we further condition on wholesale market concentration, first identically across regimes and then allowing for regime-specific relationships between concentration and pass-through rates. In neither column do we find that pass-through is strongly correlated with concentration, nor do we find that the effect of market concentration varies significantly across regimes. Most importantly, the inclusion of market concentration does not substantively affect our results related to regime-specific pass-through. This suggests that it is unlikely that market power explains the regime-specific differences in pass-through rates we observe.

\section{Pass-Through of Input Costs: A Falsification Test}

We next compare the pass-through of the price of crude oil to the pass-through of taxes. Crude oil is the primary input to diesel and other refined petroleum products; from 1986 to 2006, the cost of crude oil amounted to 60 percent of the price of diesel fuel. Importantly, the price of crude oil is set by a world market and, unlike fuel taxes, is virtually impossible to evade or avoid. Thus, estimating the pass-through of the price of crude oil comprises a falsification test of our results. Because crude oil prices cannot be evaded like taxes, if we observed that crude oil prices were passed-through less fully in states that collect from retailers than from upstream suppliers, it would suggest that our observed results were driven by unobserved differences in supply and demand elasticities rather than differential rates of evasion throughout the supply chain. ${ }^{20}$

To estimate the pass-through of crude oil prices, we extend our previous specification to include interactions of the price of crude oil with the point of diesel tax collection. ${ }^{21}$ Table 9 reports the results of four specifications. All specifications include state fixed effects as well as the set of covariates included in the regressions shown in Table 5.

In columns 1 and 2, we include a relatively coarse set of time fixed effects (month fixed effects and year fixed effects, separately) so as to allow the price of oil to enter directly into the specification. In column 1, we estimate a coefficient on oil price very close to one, implying that changes in oil prices are fully incorporated into diesel prices. We continue to find higher rates of tax pass-through in states that collect from the wholesale terminal than states that collect from the retail station, although we can no longer statistically rule out full pass-through in retailer-remitting states.

In column 2, we allow for pass-through of crude oil costs to vary based on where a state collected diesel taxes. This provides a falsification test of our main results. Finding that the pass-through for oil prices, which are impossible to evade or avoid, depends on the point of collection in a similar fashion to the estimates in Table 5 would cast doubt on whether evasion is a good explanation for the observed patterns of tax pass-through. Fortunately, we do not observe similar patterns for oil price pass-through. Although the pass-through of oil prices is significantly different in

\footnotetext{
${ }^{20}$ Note that because diesel taxes are per unit rather than proportional, the tax rate level does not change automatically when the price of crude oil changes.

${ }^{21}$ For ease of comparison, we rescale the price of crude oil to cents per gallon. Thus, a coefficient of 1 represents full pass-through of input costs.
} 
Table 9-Pass-Through of Oil Price Shocks

\begin{tabular}{lcccc}
\hline \hline & $(1)$ & $(2)$ & $(3)$ & $(4)$ \\
\hline Real diesel tax & -0.071 & -0.071 & $-0.120 * *$ & $-0.101^{*}$ \\
& $(0.057)$ & $(0.057)$ & $(0.055)$ & $(0.054)$ \\
Real tax $\times$ & $0.187 * * *$ & $0.188^{* * *}$ & $0.209 * * *$ & $0.194 * * *$ \\
$\quad$ collect from supplier & $(0.055)$ & $(0.057)$ & $(0.052)$ & $(0.054)$ \\
Real tax $\times$ & 0.082 & 0.078 & $0.100^{*}$ & 0.077 \\
$\quad$ collect from distributor & $(0.057)$ & $(0.057)$ & $(0.056)$ & $(0.055)$ \\
Real spot oil price & $0.999^{* * *}$ & $1.019 * * *$ & & \\
& $(0.063)$ & $(0.065)$ & & $-0.0244 * *$ \\
Real oil price $\times$ & & 0.0042 & & $(0.0104)$ \\
$\quad$ collect from supplier & & $(0.0129)$ & & $-0.0409 * * *$ \\
Real oil price $\times$ & & $-0.0261 * * *$ & & $(0.0078)$ \\
$\quad$ collect from distributor & & $(0.0080)$ & & \\
& & & & \\
Time FE & Month, Year & Month $\times$ Year & Month $\times$ Year \\
Observations & 5,435 & 5,435 & 5,435 & 5,435 \\
$R^{2}$ & 0.948 & 0.948 & 0.982 & 0.982 \\
\hline
\end{tabular}

Notes: The dependent variable in columns 3 and 4 is the real tax-exclusive retail price of No. 2 diesel. All variables are measured in cents per gallon. Standard errors clustered by year $\times$ month are in parentheses. The other covariates are identical to those included in the specification shown in column 3 of Table 4 . All specifications include state fixed effects. Columns 1 and 2 include year fixed effects and month fixed effects. Columns 3 and 4 include year $\times$ month fixed effects.

*** Significant at the 1 percent level.

** Significant at the 5 percent level.

* Significant at the 10 percent level.

states that collect from the distributor compared to states that collect from the retailer, the point estimate is of the wrong sign and significantly smaller in magnitude.

In columns 3 and 4, we revert to a specification that includes time fixed effects that subsume the direct effect of oil prices. Column 3 recreates the main specification from Table 5. Column 4 augments this specification by including interactions between oil price and the point of collection. As before, we do not observe similar patterns of pass-through interacted with point of collection for oil prices and taxes. Although we do observe that pass-through of oil prices is different in supplier and distributor-remitting states, the coefficients are of the opposite sign of those for the pass-through of taxes, and are much smaller in magnitude.

\section{Other Robustness Checks}

A potential concern with the specification of the pass-through rate of taxation is that taxes may be set endogenously. Tax rates may be set in response to demand or supply conditions, or endogenously along with the point of tax collection. To illustrate the potential concern, Figure 5 plots the mean state diesel tax relative to the year in which a state shifted the point of collection to the distributor (panel A) and supplier (panel B). On average, for the eight states that change the point of collection to the distributor, diesel taxes tend to increase at a faster rate in a one-year window around the change in the point of collection. We do not see a similar pattern for the 20 states that move the point of collection to the supplier. 
Panel A. Changes to distributor remittance

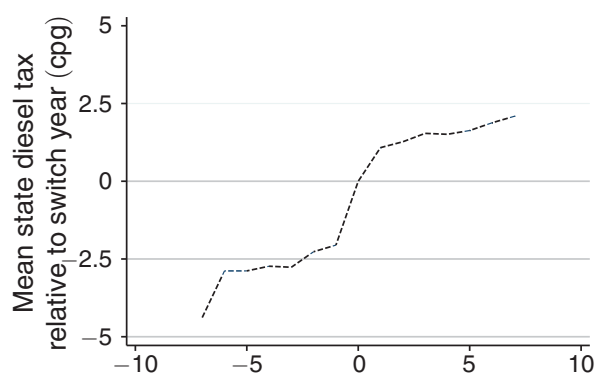

Year relative to switch to distributor remittance
Panel B. Changes to supplier remittance

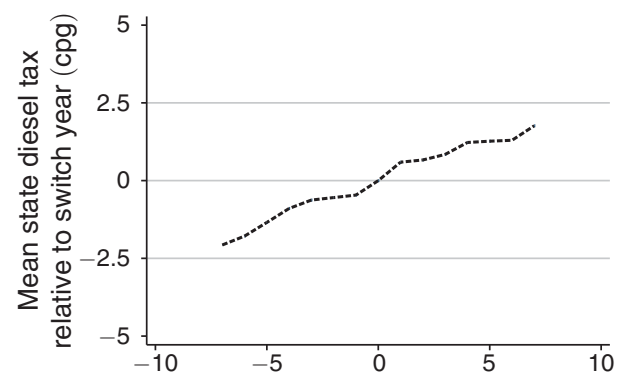

Year relative to switch to supplier remittance

Figure 5. Diesel Taxes before and after Regime Changes

Notes: The $\mathrm{x}$-axis is centered around the year in which each state changes the point of collection to the distributor (panel A) or supplier (panel B). The values on the y-axis are diesel taxes relative to the tax in the year in which the point of collection changed.

TABLE 10-OTHer RoBUstness Checks

\begin{tabular}{|c|c|c|c|c|c|c|}
\hline & \multicolumn{2}{|c|}{ Base } & \multicolumn{2}{|c|}{ Exclude $+/-2 \mathrm{yr}$} & \multirow{2}{*}{$\begin{array}{c}\text { Retailer/ } \\
\text { non-retailer } \\
(5)\end{array}$} & \multirow{2}{*}{$\begin{array}{l}\text { IV for tax } \\
\text { (6) }\end{array}$} \\
\hline & (1) & (2) & (3) & (4) & & \\
\hline Real diesel tax & $\begin{array}{r}-0.0250 \\
(0.0217)\end{array}$ & $\begin{array}{c}-0.120 * * \\
(0.0550)\end{array}$ & $\begin{array}{c}0.00402 \\
(0.0252)\end{array}$ & $\begin{array}{c}-0.0704 \\
(0.0668)\end{array}$ & $\begin{array}{c}-0.0402 * * \\
(0.0192)\end{array}$ & $\begin{array}{c}0.0854 * \\
(0.0504)\end{array}$ \\
\hline $\begin{array}{l}\text { Real tax } \times \\
\quad \text { collect from supplier }\end{array}$ & & $\begin{array}{l}0.209 * * * \\
(0.0524)\end{array}$ & & $\begin{array}{l}0.272 * * * \\
(0.0659)\end{array}$ & & \\
\hline $\begin{array}{l}\text { Real tax } \times \\
\quad \text { collect from distributor }\end{array}$ & & $\begin{array}{l}0.1000^{*} \\
(0.0556)\end{array}$ & & $\begin{array}{c}0.0624 \\
(0.0645)\end{array}$ & & \\
\hline $\begin{array}{l}\text { Real tax } \times \\
\quad \text { collect from retailer }\end{array}$ & & & & & $\begin{array}{l}-0.193 * * * \\
(0.0454)\end{array}$ & $\begin{array}{l}-0.165 * * * \\
(0.0607)\end{array}$ \\
\hline Collect from supplier & $\begin{array}{l}2.875 \text { **** } \\
(0.268)\end{array}$ & $\begin{array}{c}0.445 \\
(0.604)\end{array}$ & $\begin{array}{l}3.697 * * * \\
(0.317)\end{array}$ & $\begin{array}{c}0.550 \\
(0.712)\end{array}$ & & \\
\hline Collect from distributor & $\begin{array}{l}1.378 * * * \\
(0.188)\end{array}$ & $\begin{array}{c}0.192 \\
(0.626)\end{array}$ & $\begin{array}{l}1.528 * * * \\
(0.191)\end{array}$ & $\begin{array}{c}0.714 \\
(0.691)\end{array}$ & & \\
\hline Collect from retailer & & & & & $\begin{array}{c}0.389 \\
(0.512)\end{array}$ & $\begin{array}{c}0.0120 \\
(0.690)\end{array}$ \\
\hline Observations & 5,435 & 5,435 & 5,045 & 5,045 & 5,435 & 5,435 \\
\hline$R^{2}$ & 0.982 & 0.982 & 0.982 & 0.982 & 0.981 & 0.981 \\
\hline
\end{tabular}

Notes: The dependent variable is the real tax-exclusive retail price of No. 2 diesel. Standard errors clustered by year $\times$ month are in parentheses. The other covariates are identical to those included in the specification shown in column 3 of Table 4 . All specifications include state fixed effects and year $\times$ month effects. The instrument used for tax in column 6 is the tax rate interacted with an indicator for whether the state has employed automatic adjustment of its diesel tax rate.

*** Significant at the 1 percent level.

** Significant at the 5 percent level.

* Significant at the 10 percent level.

In Table 10, we present the results of two robustness checks meant to address this possibility. Because tax rates may change along with the point of taxation, we first drop the two years on either side of a change in the point of collection. Second, we employ an instrument for the tax rate. In the first two columns of Table 10, we display again our base incidence specifications. In columns 3 and 4, we show estimates excluding the two years immediately preceding and following the change 
of the remitting party. Doing so has little effect on the estimates of the primary coefficients of interest. The interaction between the supplier remittance indicator and the tax rate is in fact slightly larger, while the effect of distributor remittance on the pass-through rate is slightly smaller. It is worth noting that the results are robust to excluding different length windows around the policy change, such as one year on either side of the change in remitting party.

We next consider an instrument for the potentially endogenous rate of taxation. States change tax rates in two ways: either through periodic adjustments via legislation or by regular prespecified automatic adjustments. Such automatic adjustments are by definition not influenced by short-run changes in demand or supply conditions. Because there are few states with this type of policy, separately identifying the effect of retailer, distributor, and supplier remittance is not possible. We therefore simplify the categorization of remitting-party into retailer and non-retailer remitting states. In column 5 of Table 10, we present estimates of a regression that is identical to our base specification except for including an interaction between retailer remittance and the tax rate rather than the more detailed remitting-party interactions. The results show that the distinction between distributor and supplier remittance is not crucial in our base specification, as retailer-remitting states have a pass-through rate that is 19 percentage points less than non-retailer remitting states. In column 6 , we present the IV specification, where we instrument for the tax rate with an interaction between an automatically adjusting state and the tax rate. As a consequence, this specification only employs variation in the tax rate that occurs in automatically adjusting states. We obtain a very similar estimate of the effect of retailer remittance on pass-through from this plausibly exogenous source of variation in taxes, as this specification indicates that retailer remittance leads to 16.5 percentage points less of a tax rate being passed through to retail prices.

\section{E. Tax Collection Results}

We now examine how the level of taxed gallons responds to the point of taxation. As the state adjusts the point of tax collection, for a given tax rate, we interpret corresponding observed changes in tax collections as evidence of a change in tax compliance. This will provide a link between the empirical results discussed in Section IVA and the theoretical predictions in Sections I.

In Table 11, we present estimates of equation (2), which relates taxed gallons to the point of tax collection. ${ }^{22}$ Each specification includes year and state effects. The specification shown in column 1 includes only the regime dummy variables. Upstream shifts in the point of collection are associated with a higher reported tax base. For a given tax rate, compared to states taxing at the retailer level, distributor-collecting states see 3.7 percent more gallons of diesel reported to the tax authorities, and states collecting from the prime supplier collect 8.0 percent more.

\footnotetext{
${ }^{22}$ We estimate this specification in levels, although one could also justify estimating a specification of the change in taxed gallons. Estimating in changes has the advantage of examining the contemporaneous collections response. When we estimate this specification, we see that a change to supplier collection increases taxed gallons by 8.2 percent, and a change to distributor remittance increases taxed gallons by 6.7 percent. These estimates are similar to the specification in levels that we display here.
} 
Table 11-Point of Tax Collection and TaXed Gallons

\begin{tabular}{|c|c|c|c|c|c|}
\hline & (1) & (2) & (3) & (4) & (5) \\
\hline Collect from supplier & $\begin{array}{l}0.080^{* * * *} \\
(0.017)\end{array}$ & $\begin{array}{l}0.076 * * * \\
(0.016)\end{array}$ & $\begin{array}{c}0.026 \\
(0.016)\end{array}$ & $\begin{array}{l}0.37 * * * \\
(0.11)\end{array}$ & $\begin{array}{l}0.25^{* *} \\
(0.11)\end{array}$ \\
\hline Collect from distributor & $\begin{array}{l}0.037 * * * \\
(0.010)\end{array}$ & $\begin{array}{l}0.044 * * * \\
(0.013)\end{array}$ & $\begin{array}{c}0.024 \\
(0.014)\end{array}$ & $\begin{array}{l}0.16^{* * * *} \\
(0.042)\end{array}$ & $\begin{array}{l}0.15^{* * * *} \\
(0.042)\end{array}$ \\
\hline log diesel price & & $\begin{array}{c}0.32 \\
(0.25)\end{array}$ & $\begin{array}{c}0.22 \\
(0.15)\end{array}$ & $\begin{array}{c}0.20 \\
(0.15)\end{array}$ & $\begin{array}{c}0.22 \\
(0.16)\end{array}$ \\
\hline $\ln (1+t / p)$ & & $\begin{array}{l}-1.39 * * * \\
(0.27)\end{array}$ & $\begin{array}{l}-1.02 * * * \\
(0.21)\end{array}$ & $\begin{array}{l}-0.59 * * \\
(0.22)\end{array}$ & $\begin{array}{r}-0.37^{*} \\
(0.21)\end{array}$ \\
\hline Collect from supplier $\times \ln (1+t / p)$ & & & & $\begin{array}{l}-0.93 * * * \\
(0.29)\end{array}$ & $\begin{array}{r}-0.61^{*} \\
(0.30)\end{array}$ \\
\hline Collect from distributor $\times \ln (1+t / p)$ & & & & $\begin{array}{l}-0.40 * * * \\
(0.11)\end{array}$ & $\begin{array}{l}-0.34 * * * \\
(0.11)\end{array}$ \\
\hline log real minimum neighbor tax & & & $\begin{array}{c}-0.044 \\
(0.030)\end{array}$ & $\begin{array}{c}-0.043 \\
(0.030)\end{array}$ & $\begin{array}{c}-0.051 \\
(0.031)\end{array}$ \\
\hline Unemp. rate & & & $\begin{array}{l}-0.021 * * * \\
(0.0065)\end{array}$ & $\begin{array}{l}-0.021 * * * \\
(0.0067)\end{array}$ & $\begin{array}{l}-0.021 * * * \\
(0.0071)\end{array}$ \\
\hline $\log$ GSP & & & $\begin{array}{l}0.70 * * * \\
(0.046)\end{array}$ & $\begin{array}{l}0.71 * * * \\
(0.049)\end{array}$ & $\begin{array}{l}0.71 * * * \\
(0.055)\end{array}$ \\
\hline log degree days & & & $\begin{array}{l}-0.075 \\
(0.050)\end{array}$ & $\begin{array}{l}-0.073 \\
(0.050)\end{array}$ & $\begin{array}{l}-0.076 \\
(0.053)\end{array}$ \\
\hline $\log$ degree days $\times$ HH fuel oil frac. & & & $\begin{array}{c}0.25^{* *} \\
(0.092)\end{array}$ & $\begin{array}{c}0.25^{* *} \\
(0.092)\end{array}$ & $\begin{array}{c}0.25^{* *} \\
(0.093)\end{array}$ \\
\hline Diesel tax $\times$ year dummies & & & & & $\mathrm{X}$ \\
\hline Observations & 1,029 & 1,029 & 987 & 987 & 987 \\
\hline$R^{2}$ & 0.99 & 0.99 & 0.99 & 0.99 & 0.99 \\
\hline
\end{tabular}

Notes: The dependent variable is the log of the annual number of gallons of special fuel on which state taxes were collected. The unit of observation is at the year-state level. Standard errors clustered by year are in parentheses. Each specification includes year and state effects. If a regime change occurred mid-year, the regime change dummy is equal to the proportion of months the regime was in effect.

*** Significant at the 1 percent level.

** Significant at the 5 percent level.

* Significant at the 10 percent level.

Column 2 presents the results of a specification that includes the log tax exclusive price and the $\log$ percentage tax rate, defined as $\log (1+t / p)$, where $p$ is the mean price experienced by the state over the course of the sample. The point estimates on the tax collection regimes are unaffected by the inclusion of price and tax variables.

The specification shown in column 3 includes further covariates. This attenuates the collection regime dummy variables, and the coefficients on these variables are now only of marginal statistical significance. Part of this may be explained by the change in tax elasticity upon a change in the tax regime. In column 4, we show estimates from a specification that allows for an interaction between the tax rate and the collection regime. We see that taxed gallons are less elastic in the post-regime period. Lastly, in column 5 , we also include a full set of year $\times$ tax rate interactions. As with the price specification where we included a similar set of controls, this specification addresses the concern that the price responsiveness of consumers of diesel may have changed over time. Including these controls does not have a noticeable effect on the coefficients of interest. 


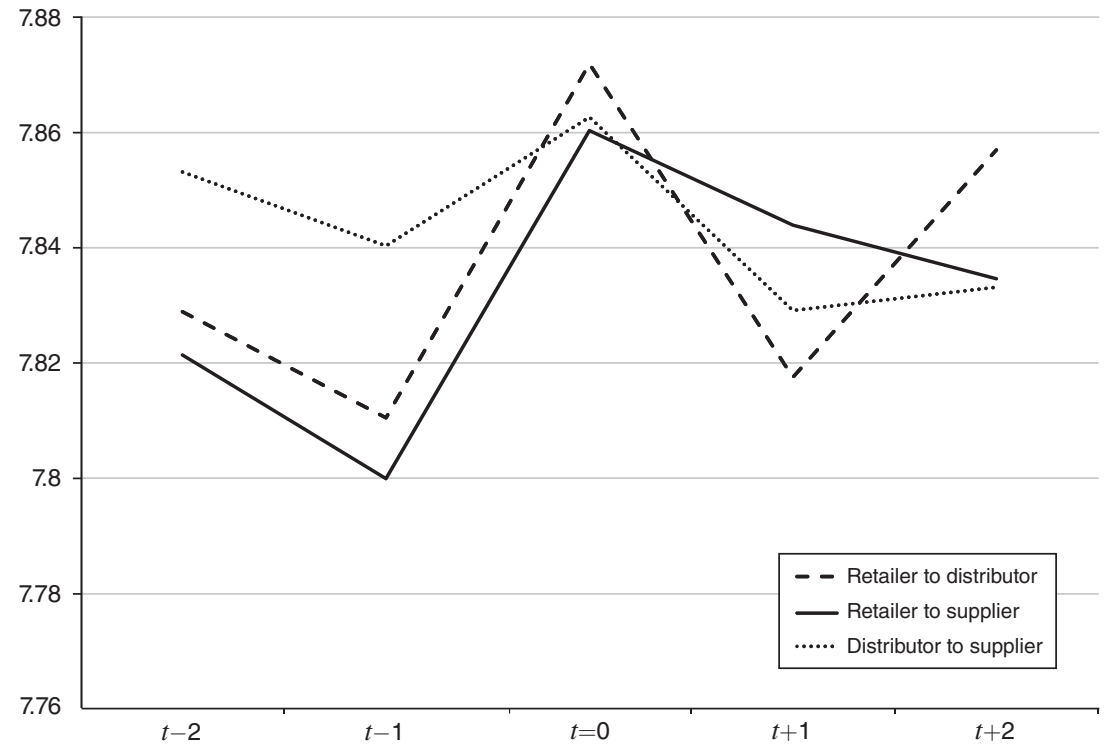

Average log taxed gallons of diesel by year relative to collection regime change. Year and state effects removed

Figure 6. Collection Regime Shifts and Taxed Gallons

Notes: The x-axis is centered around the year in which a state changes the point of collection. The values on the $y$-axis are the residuals from the regression of taxed gallons on state and year fixed effects.

Because the regressions are estimated in levels, they miss the timing of the response of collections to the change in the collection regime. We now explore the timing of the response of tax collections to the change in the collection regime, as well as consider any pre- or post-change trends in tax collections. In Figure 6, we plot the average residual taxed gallons, taking out year and state effects, in each year from two years before the change in the collection regime to two years after.

Compared to states that move the point of collection from the distributor to the supplier, and hence are already collecting the tax above the retail level, tax collections are initially lower in states that move the point of collection away from the retail level. This is true regardless of whether the state will ultimately move the collection point to the distributor or the prime supplier. As suggested by the regression results presented in Table 11, states moving the point of collection away from the retailer experience a jump in collections in the year of the policy change. Importantly, average tax collections were similar in all three cases after the change in collection regime. Despite the fact that states that initially collected from the distributor had tax collections around 3 percent higher, the average of the post-reform coefficients for each of the three types of regime changes are within 0.7 percent of one another.

\section{Conclusion}

The independence between equilibrium tax-inclusive prices and the side of the market taxed is a key principle that a student of public finance learns in the study of tax theory. This paper presents the first estimates of how prices may in fact respond 
to the identity of the tax remitter and provides evidence that the source of this result is variation in the ability to evade taxes across potential remitters of a given tax rate. This result has potentially important implications in understanding the distributional impact and revenue calibration of taxation in markets where evasion is prevalent.

Our results are directly applicable to the current debate on whether carbon taxes should be levied on upstream energy producers or downstream energy users. The current literature weights the administrative, political, and distribution advantages and disadvantages of each, but largely ignores tax incidence, effectively assuming that the incidence of a carbon tax levied on energy producers and energy users would be identical. Although it is impossible to assess opportunities for outright evasion of a hypothetical carbon tax, a major part of the debate focuses on the ability of firms to avoid a carbon tax by increasing production in unregulated jurisdictions. If those opportunities differ substantially for energy producers and energy users, incidence may be affected by the point of remittance in a very similar way to the context we examine.

\section{REFERENCES}

Agostini, Claudio A., and Claudia Martínez A. 2014. "Response of Tax Credit Claims to Tax Enforcement: Evidence from a Quasi-Experiment in Chile." Fiscal Studies 35 (1): 41-65.

Alm, James, Edward Sennoga, and Mark Skidmore. 2009. "Perfect Competition, Urbanicity, and Tax Incidence in the Retail Gasoline Market." Economic Inquiry 47 (1): 118-34.

Balke, Nathan S., and Grant W. Gardner. 1991. "Tax Collection Costs and the Size of Government." Unpublished.

Baluch, Stephen. 1996. "Revenue Enhancement Through Increased Motor Fuel Tax Enforcement." Transportation Research Record 1558: 67-73.

Barnett, Paul G., Theodore E. Keeler, and Teh-wei Hu. 1995. "Oligopoly Structure and the Incidence of Cigarette Excise Taxes." Journal of Public Economics 57 (3): 457-70.

Besley, Timothy J., and Harvey S. Rosen. 1999. "Sales Taxes and Prices: An Empirical Analysis." National Tax Journal 52 (2): 157-78.

Brownlee, Oswald, and George Perry. 1967. "The Effects of the 1965 Federal Excise Tax Reduction on Prices." National Tax Journal 20 (3): 235-49.

Chernick, Howard, and Andrew Reschovsky. 1997. "Who Pays the Gasoline Tax?" National Tax Journal 50 (2): 233-59.

Chiou, Lesley, and Erich Muehlegger. 2014. "Consumer Response to Cigarette Excise Tax Changes." National Tax Journal 67 (3): 621-50.

Chouinard, Hayley, and Jeffrey M. Perloff. 2004. "Incidence of federal and state gasoline taxes." Economics Letters 83 (1): 55-60.

Chouinard, Hayley, and Jeffrey M. Perloff. 2007. "Gasoline Price Differences: Taxes, Pollution, Regulations, Mergers, Market Power, and Market Conditions." B. E. Journal of Economic Analysis and Policy 7 (1): 1-26.

Delipalla, Sophia, and Owen O'Donnell. 2001. "Estimating tax incidence, market power and market conduct: The European cigarette industry." International Journal of Industrial Organization 19 (6): 885-908.

de Paula, Áureo, and Jose A. Scheinkman. 2010. "Value-Added Taxes, Chain Effects, and Informality." American Economic Journal: Macroeconomics 2 (4): 195-221.

Doyle, Joseph J., Jr., and Krislert Samphantharak. 2008. “\$2.00 Gas! Studying the effects of a gas tax moratorium." Journal of Public Economics 92 (3): 869-84.

Due, John F. 1954. "The Effect of the 1954 Reduction in Federal Excise Taxes upon the List Prices of Electrical Appliances: A Case Study." National Tax Journal 7 (3): 222-26.

Fischer, Carolyn, Suzi Kerr, and Michael Toman. 1998. "Using Emissions Trading to Regulate U.S. Greenhouse Gas Emissions: An Overview of Policy Design and Implementation Issues." National Tax Journal 51 (3): 453-64.

Fochmann, Martin, and Joachim Weimann. 2013. "The Effects of Tax Salience and Tax Experience on Individual Work Efforts in a Framed Field Experiment." Public Finance Analysis 69 (4): 511-42. 
Fullerton, Don, and Gilbert E. Metcalf. 2002. "Tax incidence." In Handbook of Public Economics, Vol. 4, edited by Alan J. Auerbach and Martin Feldstein, 1787-1872. Amsterdam: North-Holland.

Harding, Matthew, Ephraim Leibtag, and Michael F. Lovenheim. 2012. "The Heterogeneous Geographic and Socioeconomic Incidence of Cigarette Taxes: Evidence from Nielsen Homescan Data." American Economic Journal: Economic Policy 4 (4): 169-98.

Hastings, Justine S. 2004. "Vertical Relationships and Competition in Retail Gasoline Markets: Empirical Evidence from Contract Changes in Southern California." American Economic Review 94 (1): 317-28.

Hayashi, Andrew T., Brent K. Nakamura, and David Gamage. 2013. "Experimental Evidence of Tax Salience and the Labor-Leisure Decision: Anchoring, Tax Aversion, or Complexity." Public Finance Review 41 (2): 203-26.

Houde, Jean-Francois. 2012. "Spatial Differentiation and Vertical Mergers in Retail Markets for Gasoline." American Economic Review 102 (5): 2147-82.

Kau, James B., and Paul H. Rubin. 1981. "The size of government.” Public Choice 37 (2): 261-74.

Kopczuk, Wojciech. 2005. "Tax bases, tax rates and the elasticity of reported income." Journal of Public Economics 89 (11): 2093-2119.

Kopczuk, Wojciech, Justin Marion, Erich Muehlegger, and Joel Slemrod. 2016. "Does Tax-Collection Invariance Hold? Evasion and the Pass-Through of State Diesel Taxes: Dataset." American Economic Journal: Economic Policy. http://dx.doi.org/10.1257/pol.20140271.

Lehmann, Etienne, François Marical, and Laurence Rioux. 2013. "Labor Income Responds Differently to Income-Tax and Payroll-Tax Reforms." Journal of Public Economics 99 (1): 66-84.

Marion, Justin, and Erich Muehlegger. 2008. "Measuring Illegal Activity and the Effects of Regulatory Innovation: Tax Evasion and the Dyeing of Untaxed Diesel.” Journal of Political Economy 116 (4): 633-66.

Marion, Justin, and Erich Muehlegger. 2011. "Fuel tax incidence and supply conditions." Journal of Public Economics 95 (9): 1202-12.

Metcalf, Gilbert E. 2009. "Designing a Carbon Tax to Reduce U.S. Greenhouse Gas Emissions." Review of Environmental Economics and Policy 3 (1): 63-83.

Musgrave, Richard A. 1969. Fiscal Systems. New Haven: Yale University Press.

Muysken, Joan, Tom van Veen, and Erik de Regt. 1999. "Does a Shift in the Tax Burden Create Employment?" Applied Economics 31 (10): 1195-1205.

Niemeier, D., Gregory Gould, Alex Karner, Mark Hixson, Brooke Bachmann, Carrie Okma, Ziv Lang, et al. 2008. "Rethinking downstream regulation: California's opportunity to engage households in reducing greenhouse gases." Energy Policy 36 (9): 3436-47.

Pomeranz, Dina. 2013. "No Taxation without Information: Deterrence and Self-Enforcement in the Value Added Tax." National Bureau of Economic Research (NBER) Working Paper 19199.

Poterba, James M. 1996. "Retail Price Reactions to Changes in State and Local Sales Taxes." National Tax Journal 49 (2): 165-76.

Rothstein, Jesse. 2010. "Is the EITC as Good as an NIT? Conditional Cash Transfers and Tax Incidence." American Economic Journal: Economic Policy 2 (1): 177-208.

Saez, Emmanuel, Manos Matsaganis, and Panos Tsakloglou. 2012. "Earnings Determination and Taxes: Evidence from a Cohort-Based Payroll Tax Reform in Greece." Quarterly Journal of Economics 127 (1): 493-533.

Sidhu, Nancy Dayton. 1971. "Effects of Changes in Sales Tax Rates on Retail Prices.” In Proceedings of the Annual Conference on Taxation under the Auspices of the National Tax Association, Vol. 64, edited by Stanley J. Bowers, 720-33. Columbus: National Tax Association.

Slemrod, Joel. 2001. "A General Model of the Behavioral Response to Taxation." International Tax and Public Finance 8 (2): 119-28.

Slemrod, Joel. 2008. "Does It Matter Who Writes the Check to the Government? The Economics of Tax Remittance." National Tax Journal 61 (2): 251-75.

Slemrod, Joel, and Wojciech Kopczuk. 2002. "The optimal elasticity of taxable income." Journal of Public Economics 84 (1): 91-112.

Slemrod, Joel, and Caroline Weber. 2012. "Evidence of the Invisible? Measurement Issues in Analyzing Tax Evasion and the Informal Economy." International Tax and Public Finance 19 (1): $25-53$.

Sørensen, Peter Birch. 1994. "From the Global Income Tax to the Dual Income Tax: Recent Tax Reforms in the Nordic Countries." International Tax and Public Finance 1 (1): 57-79.

Sunng, Hai-Yen, Teh-wei Hu, and Theodore E. Keeler. 1994. "Cigarette Taxation and Demand: An Empirical Model.” Contemporary Economic Policy 12 (3): 91-100.

Tanzi, Vito. 1992. "Theory and Policy: A Comment on Dixit and on Current Theory." IMF Staff Papers 39 (4): 957-66. 
Weimar, Mark, Patrick Balducci, Eihab Fathelrahman, Susan Whitmore, and Anthony Rufolo. 2008. "Identifying and Quantifying Rates of State Motor Fuel Tax Evasion." National Cooperative Highway Research Program (NCHRP) Report 623.

Weyl, E. Glen, and Michael Fabinger. 2013. "Pass-Through as an Economic Tool: Principles of Incidence under Imperfect Competition.” Journal of Political Economy 121 (3): 528-83.

Woodard, F. O., and Harvey Siegelman. 1967. "Effects of the 1965 Federal Excise Tax Reduction upon the Prices of Automotive Replacement Parts: A Case Study in Tax Shifting and Pyramiding." National Tax Journal 20 (3): 250-57. 